UMETNOSTNOZGODOVINSKI INŠTITUT FRANCETA STELETA ZRC SAZU

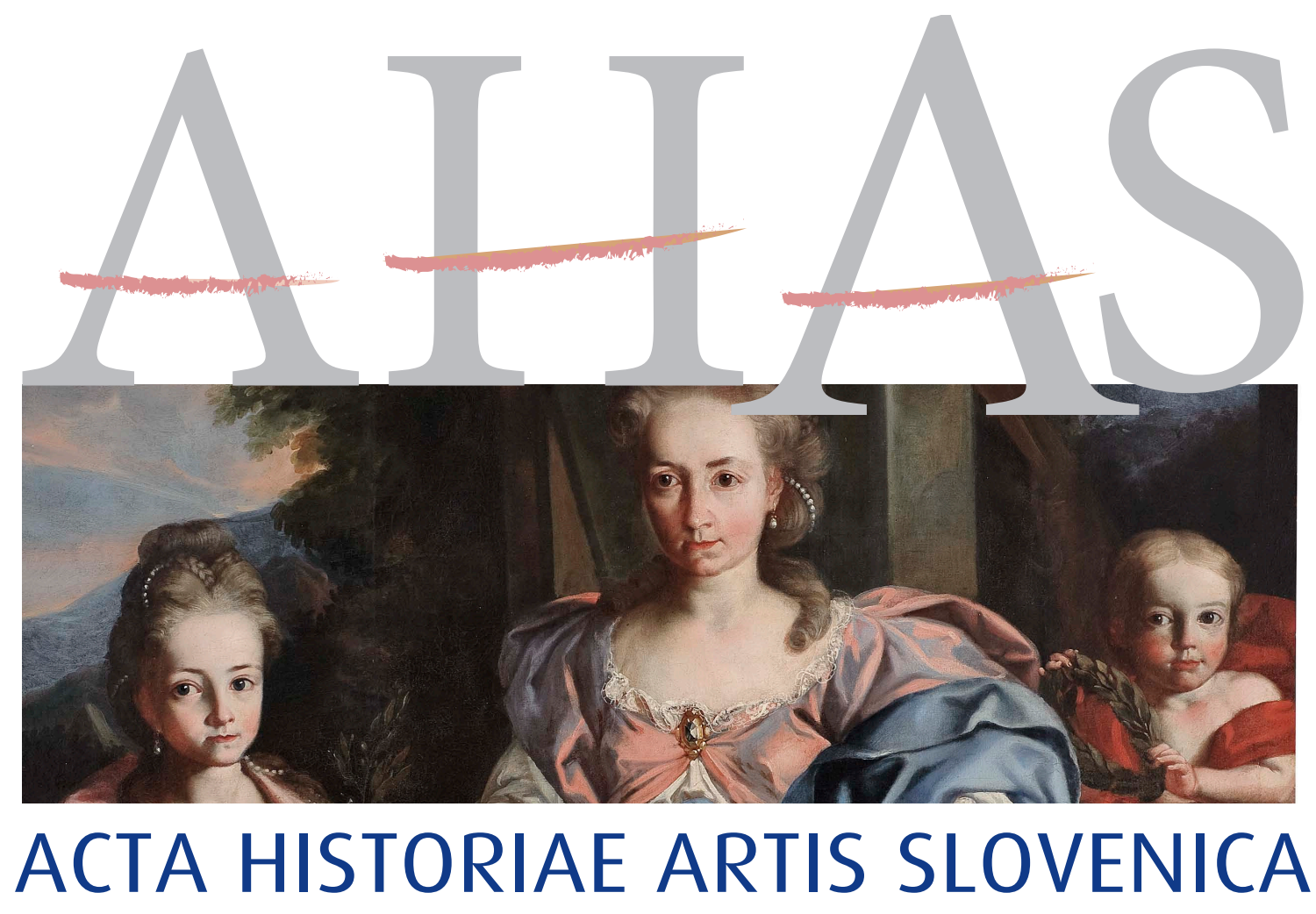

$23 \mid 1 \cdot 2018$ 
Umetnostnozgodovinski inštitut Franceta Steleta ZRC SAZU

France Stele Institute of Art History ZRC SAZU

\section{ACTA HISTORIAE ARTIS SLOVENICA}

$23 \mid 1 \cdot 2018$ 
Acta historiae artis Slovenica, 23/1, 2018

Znanstvena revija za umetnostno zgodovino / Scholarly Journal for Art History

ISSN 1408-0419 (tiskana izdaja / print edition)

ISSN 2536-4200 (spletna izdaja / web edition)

Izdajatelj / Issued by

ZRC SAZU, Umetnostnozgodovinski inštitut Franceta Steleta/

ZRC SAZU, France Stele Institute of Art History

Založnik / Publisher

Založba ZRC

Urednica / Editor

Tina Košak

Uredniški odbor / Editorial board

Tina Košak, Ana Lavrič, Barbara Murovec, Mija Oter Gorenčič, Blaž Resman, Helena Seražin

Mednarodni svetovalni odbor / International advisory board

Günter Brucher (Salzburg), Iris Lauterbach (München), Hellmut Lorenz (Wien), Milan Pelc (Zagreb),

Paola Rossi (Venezia), Sergio Tavano (Gorizia-Trieste), Barbara Wisch (Cortland, USA)

Lektoriranje / Language editing

Tina Bratuša, Aleksandra Čehovin, Kirsten Hempkin, Amy Anne Kennedy, Blaž Resman, Anke Schlecht

Prevodi / Translations

Nicole Burgund, Tina Košak, Andreja Rakovec, Nika Vaupotič, Polona Vidmar

Oblikovna zasnova in prelom / Design and layout

Andrej Furlan

Naslov uredništva / Editorial office address

Acta historiae artis Slovenica

Novi trg 2, p. p. 306, SI -1001 Ljubljana, Slovenija

E-pošta / E-mail: ahas@zrc-sazu.si

Spletna stran / Web site: http://uifs1.zrc-sazu.si

Revija je indeksirana $v$ / Journal is indexed in

Scopus, ERIH PLUS, EBSCO Publishing, IBZ, BHA

Letna naročnina / Annual subscription: $35 €$

Posamezna enojna številka / Single issue: $25 €$

Letna naročnina za študente in dijake: $25 €$

Letna naročnina za tujino in ustanove / Annual Subscription outside Slovenia, institutions: $48 €$

Naročila sprejema / For orders contact

Založba ZRC

Novi trg 2, p. p. 306, SI-1001, Slovenija

E-pošta / E-mail: zalozba@zrc-sazu.si

AHAS izhaja s podporo Javne agencije za raziskovalno dejavnost Republike Slovenije.

AHAS is published with the support of the Slovenian Research Agency.

(c) 2018, ZRC SAZU, Umetnostnozgodovinski inštitut Franceta Steleta, Založba ZRC, Ljubljana

Tisk / Printed by Cicero d. o. 0., Begunje

Naklada / Print run: 400 


\section{VSEBINA}

\section{Contents}

Milček Komelj

Ob 70-letnici Umetnostnozgodovinskega inštituta Franceta Steleta.

Nagovor na slavnostni akademiji 14. decembra 2017 v Prešernovi dvorani SAZU .......................................

France Stele Institute of Art History's 70th Anniversary.

The Opening Speech at the Celebration on 14 December 2017 at the Prešeren Hall SAZU

\section{DISSERTATIONES}

Mija Oter Gorenčič

Pro remedio et pro salute animae nostrae. Memoria v srednjeveškem umetnostnem okrasju cisterce $v$ Stični kot odsev tesne povezanosti s plemstvom

Pro remedio et pro salute animae nostrae. Memoria in Medieval Architectural

Decoration of the Stična Cistercian Monastery as a Reflection of its Close Connection

with the Nobility

Janez Premk

Maribor Synagogue Reexamined

Mariborska sinagoga pod drobnogledom

Friedrich Polleroß

Die Immaculata, Kaiser Leopold I., und ein römisches Thesenblatt der Laibacher Franziskaner 93

Brezmadežna, cesar Leopold I. in rimski tezni list ljubljanskih frančiškanov

Barbara Murovec

Historizirana podoba naročnika. Attemsova družinska portreta iz brežiškega gradu in Rembov avtoportret

The Patron's Historized Image. Attems' Family Portraits and Remp's

Self-Portrait in the Brežice (Rann) Castle

Vesna Krmelj

France Stele v luči mladostne korespondence z Izidorjem Cankarjem..

An Insight into France Stele through his Early Adulthood Correspondence with Izidor Cankar 
Tanja Zimmermann

Oto Bihalji-Merin and the Concept of the "Naïve" in the 1950s.

Bridging Socialist Realism and Non-Figurative Art

Oto Bihalji-Merin in koncept »naivnih $v$ petdesetih letih 20. stoletja.

Most med socialističnim realizmom in nefiguralno umetnostjo

Jasmina Čubrilo

Yugoslav: Toponym or Ideology in Miodrag B. Protićs Art-Historical

Systematization of 20th-Century Art

Jugoslovansko: toponim ali ideologija $v$ umetnostnozgodovinski sistematizaciji

umetnosti 20. stoletja $v$ besedilih Miodraga B. Protića.

\section{MISCELLANEA}

Damjan Prelovšek

Plečnikov prizidek $k$ bratovi hiši v Trnovem

Jože Plečnik's Extension of his Brother Andrej's House in Trnovo

\section{APPARATUS}

Izvlečki in ključne besede/Abstracts and keywords

Sodelavci / Contributors

Viri ilustracij / Photographic credits 


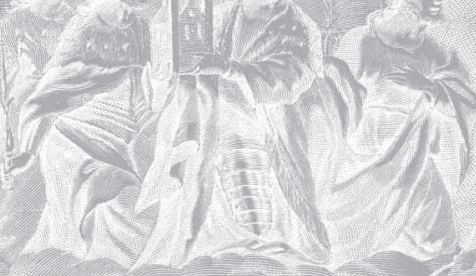

絖
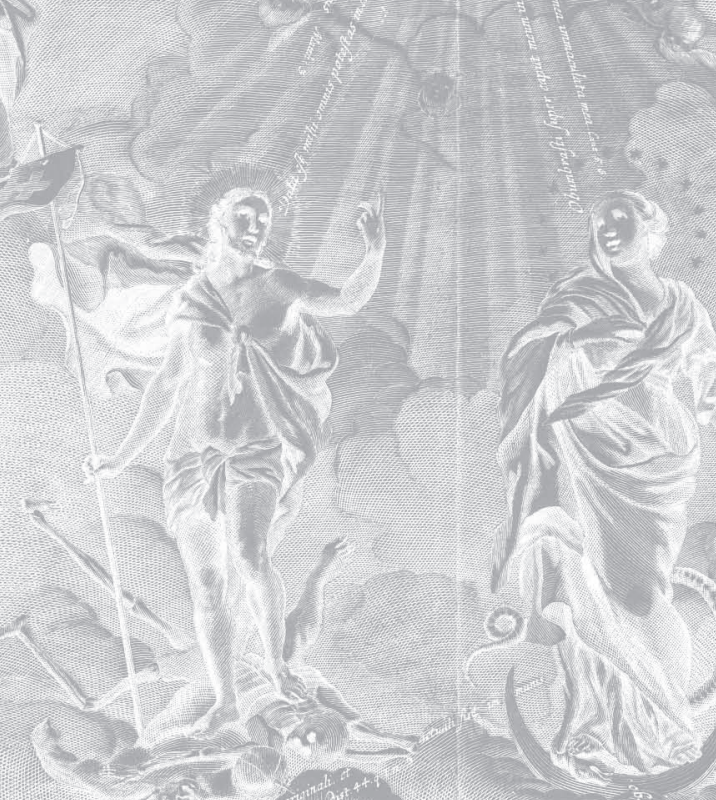

\section{DISSERTATIONES}

\section{.}

.
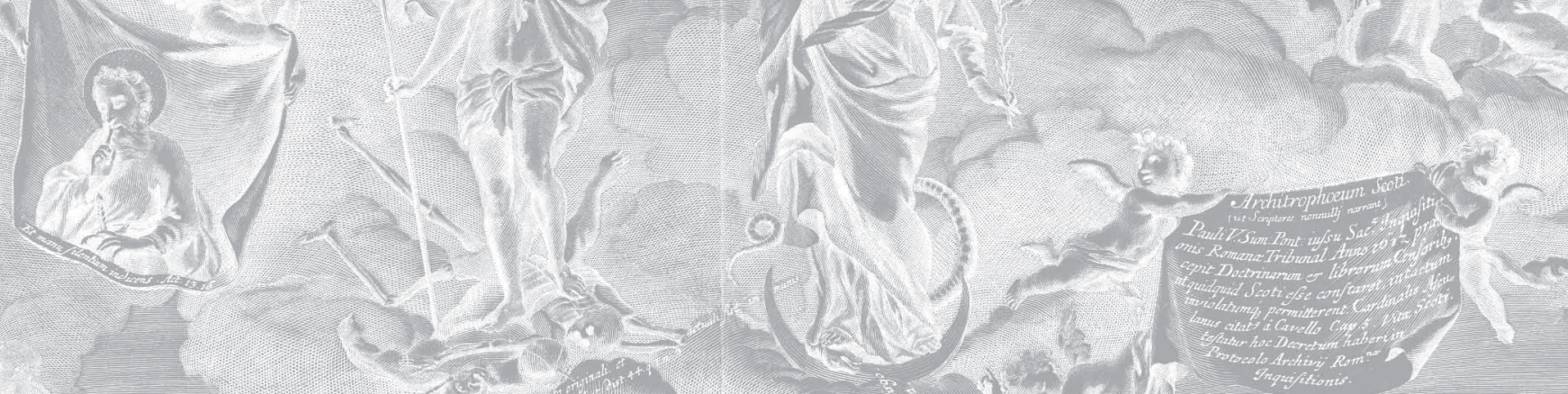

a 9
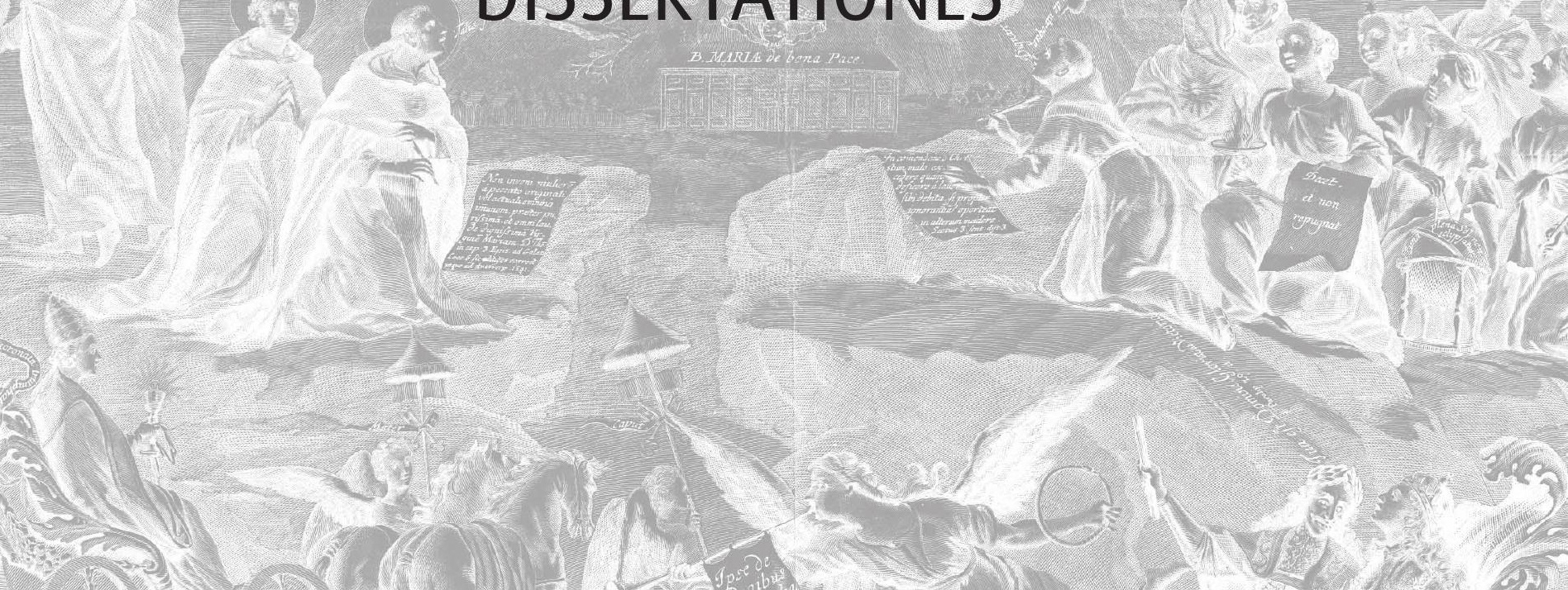
Fin

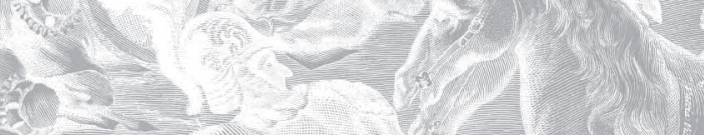




\title{
Maribor Synagogue Reexamined
}

\author{
Janez Premk
}

The last two decades have seen enormous advances in our knowledge and understanding of medieval and modern synagogue architecture in Europe, a result not only of individual and institutional initiatives in various parts of the continent (such as Simon Paulus and his colleagues at the Technical University of Braunschweig in cooperation with the Center for Jewish Art (CJA), Hebrew University of Jerusalem, and the Synagoga Slovaca initiative led by Maros Borsky), but also of new methodological approaches and practices backed by general technological advancements. ${ }^{1}$ These advances can also be seen in the evolution of medieval archaeology, resulting in not only extensive documentation $^{2}$ but also numerous virtual 3D-CAD and material reconstructions of medieval Jewish sites. ${ }^{3}$ European initiatives and accomplishments in the field of Jewish heritage, synagogue architecture, and other Jewish community buildings in Europe, have provided new insights and clues to the history of Jewish civilisation and its role within Christian society. ${ }^{4}$ Research work in this field has been presented to the general public at numerous educational events and exhibitions, with the restored sites in some cases becoming a lucrative tourist destination. ${ }^{5}$ Extensive restoration projects of former

1 Simon PAULUS, Die Architektur der Synagoge im Mittelalter. Überlieferung und Bestand, Petersberg 2007 (Schriftenreihe der Bet-Tfila-Forschungsstelle für Jüdische Architektur in Europa, 4). See also Martha KEIL, Gemeinde und Kultur. Die mittelalterlichen Grundlagen jüdischen Lebens in Österreich, Geschichte der Juden in Österreich (eds. Eveline Brugger, Herwig Wolfram), Wien 2006 (Österreichische Geschichte. Ergänzungsband), p. 17; Maros BORSKY, Synagogue Architecture in Slovakia. A Memorial Landscape of a Lost Community, Bratislava 2007.

2 The foremost institution involved in the documentation of various aspects of Jewish Art and heritage is the Center for Jewish Art (CJA) at the Hebrew University of Jerusalem, Israel. The centre was one of the first to undertake digital reconstruction of former synagogues. See http://cja.huji.ac.il/ (accessed: 1 July 2018). One of the sections of their electronic database is Jewish architecture; see The Bezalel Narkiss Index of Jewish Art, http://cja.huji.ac.il/ browser.php? mode=main (accessed: 1 July 2018).

3 Synagogen, Mikwen, Siedlungen. Jüdisches Alltagsleben im Lichte neuer archäologischer Funde (eds. Egon Wamers, Fritz Backhaus), Frankfurt am Main 2004 (Schriften des Archäologischen Museums Frankfurt, 19). Ole HARCK, Archäologische Studien zum Judentum in der europäischen Antike und dem zentraleuropäischen Mittelalter, Petersberg 2014 (Schriftenreihe der Bet Tfila-Forschungsstelle für jüdische Architektur in Europa, 7). Technical University Darmstadt also contributed significantly to the field of medieval synagogue architecture by making 3D-CAD reconstructions of interiors. An internet archive was established, partly accessible online at: http://www. cad.architektur.tu-darmstadt.de/synagogen/inter/menu.html (accessed: 1 July 2018).

4 For updated information on projects, dilemmas, findings, etc. see Jewish Heritage Europe http://jewish-heritageeurope.eu/ (accessed: 6 June 2018), an expanding web portal for a wide range of news, information and resources concerning Jewish monuments and heritage sites all over Europe. The site is currently administered by Ruth Ellen-Gruber, an expert journalist on Jewish Heritage in (Eastern) Europe.

5 In 2017, a conference was held in Venice on Jewish Heritage Tourism in Europe in the digital age, involving some of the most renowned experts on Jewish heritage as well as directors of Jewish museums and curators. The main 


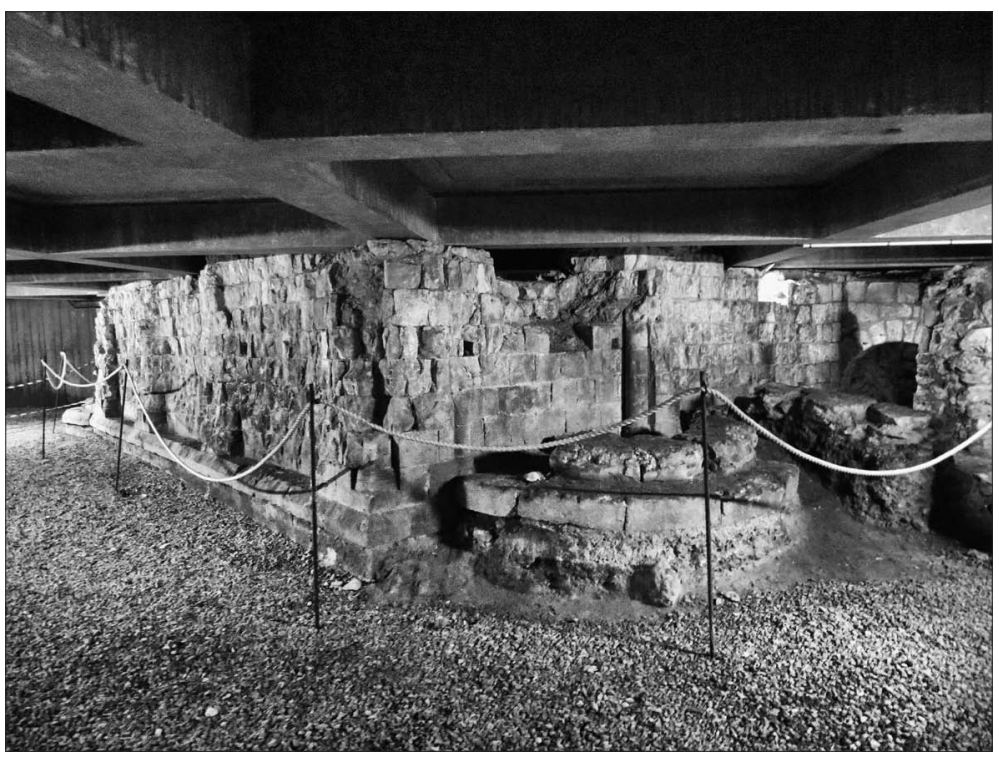

1. Maison Sublime,

Rouen, France, c. 1000

Jewish buildings have proven to be extremely challenging in many cases and initiatives and knowhow on site preservation have often turned out to be insufficient. Lack of resources is more often than not a key issue. A good example is the supposedly oldest Jewish building in France, the socalled Maison Sublime in Rouen (fig. 1). ${ }^{6}$ The Maison was discovered in 1976, dated to around 1100, and interpreted by scholars as either a private residence, synagogue, or yeshiva (Jewish school). Yet, in spite of the abundance of evidence and scientific literature on the building, it took nearly half a century for it to be restored and opened to the public in 2018. ${ }^{7}$

In the early 1990s, when the decision to restore the former synagogue in Maribor was taken, academic literature on the general history of medieval synagogue architecture in Europe was relatively scarce. Initial forays into research were made by Richard Krautheimer, who carried out systematic research on the stylistic and typological features of the more distinctive medieval synagogues as documented in the first quarter of the 20th century by the Society for the Study of Jewish Artistic Heritage (Gesellschaft zur Erforschung jüdischer Kunstdenkmäler) in Frankfurt am Main. ${ }^{8}$ There were numerous publications following Krautheimer's work, but they were either locally focused or lacked a typological and stylistic overview. Carol Herselle Krinsky produced a detailed overview of the European synagogues through the centuries in the 1980s, which also

focus of the conference was on the challenges and opportunities posed by Jewish heritage tourism and travel in Europe. For the video recordings of papers, see the website Jewish Heritage Europe, http://jewish-heritageeurope.eu/2017/10/31/jewish-heritage-tourism-in-the-digital-age-conference/ (accessed: 1 July 2018).

6 See the site's official website, La Maison Sublime de Rouen, http://www.lamaisonsublime.fr/ (accessed: 1 July 2018); Jacques-Sylvain KLEIN, La Maison Sublime. L'École rabbinique \& le Royaume juif de Rouen, Rouen-Bonsecours 2006.

7 The restoration of the Maison Sublime was accompanied by a major exhibition on medieval Jewish life and culture in northern Europe, organised by the Musée des Antiquités in Rouen. See http://museedesantiquites.fr/fr/expositions/savants-et-croyants (accessed: 1 July 2018). See also PAULUS 2007 (n. 1), pp. 473-476.

8 Richard KRAUTHEIMER, Mittelalterliche Synagogen, Berlin 1927. His work was a cornerstone for the future research of medieval synagogues of Europe, and is still relevant today. A thorough investigation of literature and sources on medieval synagogue architecture in Europe was presented by Simon Paulus in the introduction to his book; PAULUS 2007 (n. 1), p. 14. 
included some Austrian medieval synagogues and Balkan post-medieval synagogues. ${ }^{9}$ But neither of the authors mentioned Maribor synagogue, which was practically unknown to the general public at the time. Maribor synagogue only became known to foreign academic circles after the report of the U.S. Commission for the Preservation of America's Heritage Abroad was published by Ruth Ellen and Samuel Gruber in 1998 and when the first reports and articles on restoration procedures were issued by the Maribor Regional Office of the Institute for the Protection of Cultural Heritage of Slovenia (IPCHS). ${ }^{10}$

In the nearly two decades since the work on Maribor synagogue was completed (1999), and since the building began to serve as a cultural centre (2001), or independent public institution known as the Center of Jewish Cultural Heritage Synagogue Maribor, there has been a complete transformation. The Jewish quarter and synagogue, as part of the old city centre, underwent extensive renovation beginning in the 1980s; the reconstruction of the former synagogue between 1992 and 1999 is heralded as one of its main achievements. Because of its immense historical and architectural significance, it has not only become one of the most distinguished tourist sites in Maribor but has also garnered wide recognition in scholarly circles. ${ }^{11}$ The restored synagogue phase became one of the foremost examples of the Austrian medieval Ashkenazi synagogue typology. ${ }^{12}$ One of the reasons for this is that the core of the building, in spite of extensive modifications throughout the centuries and the ravages of the Second World War, remains intact. However, despite the best efforts of the professional staff involved in the restoration of the synagogue in the 1990s, some crucial questions still remained unanswered. ${ }^{13}$ The preservation of Maribor synagogue in the 1990s has

9 Carol Herselle KRINSKY, Synagogues of Europe. Architecture, History, Meaning, New York 1985.

10 Janez MIKUŽ, Jewish Temple - the Synagogue in Maribor. Report on Archeological Excavations, Maribor 1994; Gabrielle SED-RAJNA, Die jüdische Kunst, Freiburg im Breisgau-Basel-Wien 1997 (Ars antiqua); Irena KRAJNC HORVAT, Sinagoga - simbol in identiteta židovstva, Letno poročilo. Zavod za varstvo kulturne dediščine Maribor, Maribor 1999, pp. 42-49; Janez MIKUŽ, Sinagoga v Mariboru. Raziskave, rekonstrukcija, restavracija in prezentacija, Letno poročilo 1999 (n. 10), pp. 18-41; Ruth Ellen GRUBER, Samuel GRUBER, Jewish Monuments in Slovenia, Judovski zbornik, Maribor 2000 (= Časopis za zgodovino in narodopisje, n. s. 36/1-2), pp. 135-157; Janez MIKUŽ, Nekdanja židovska četrt in nekdanja sinagoga v Mariboru, Judovski zbornik 2000 (n. 10), pp. 159-171; Irena KRAJNC HORVAT, Janez MIKUŽ, Sinagoga v Mariboru nekoč in danes/The Synagogue in Maribor from Past to Future, Maribor 2000 (Muzejski listi, 20).

11 Maribor synagogue acquired the status of cultural monument of national significance in 2015. See Odlok o razglasitvi Sinagoge v Mariboru za kulturni spomenik državnega pomena, Uradni list, nr. 62/2015, 28. 8. 2015, p. 7485. The three principle reasons were: the exceptional cultural significance of the synagogue, the synagogue as a spatial dominant in Maribor and finally the fact it is the only preserved medieval Jewish sanctuary in Slovenia and one of the rare examples in Europe.

12 PAULUS 2007 (n. 1), pp. 401-404, 515; Sandra GLATZ, Synagogen des Mittelalters und der frühen Neuzeit im Raum Niederösterreich. Virtuelle Rekonstruktion der Synagogen von Oberwaltersdorf und Ebenfurth, Wien 2013 (unpublished master thesis), pp. 12-14. Involving students of architecture in the research of former synagogues, drawing groundplans, 3D models and combing the archives is not only important for widening the circle of potential future experts in the topic, but is also cost-effective. The results are especially promising if the mentor is an expert in the history of Jewish architecture or Jewish art. An interdisciplinary approach usually brings better results.

13 The preservation of Jewish heritage carried out by non-Jewish experts or at least people unfamiliar with Jewish civilisation always presents a special challenge. That was definitely the case with the restoration of Maribor synagogue. Therefore, the Maribor Regional Office of the IPCHS and its director Janez Mikuž, in charge of the synagogue restoration, consulted and cooperated with individual international experts, such as the architect and art historian Rudolf Klein from Hungary and the architect and town planner Ofer Gaon from Israel, who even spent a week in Maribor and issued a professional report with guidelines for the synagogue restoration. See IPCHS, Maribor Regional Office, Fond Maribor - Sinagoga, A letter from Ofer Gaon to Janez Mikuž, 3 October 1997. However, although foreign experts were (at least briefly) consulted, which is understandable and necessary in such complex projects, it is harder to understand why other experts willing to share their knowledge were not included in the debate or at least briefed about the progress. There was obviously enough time, because of the 


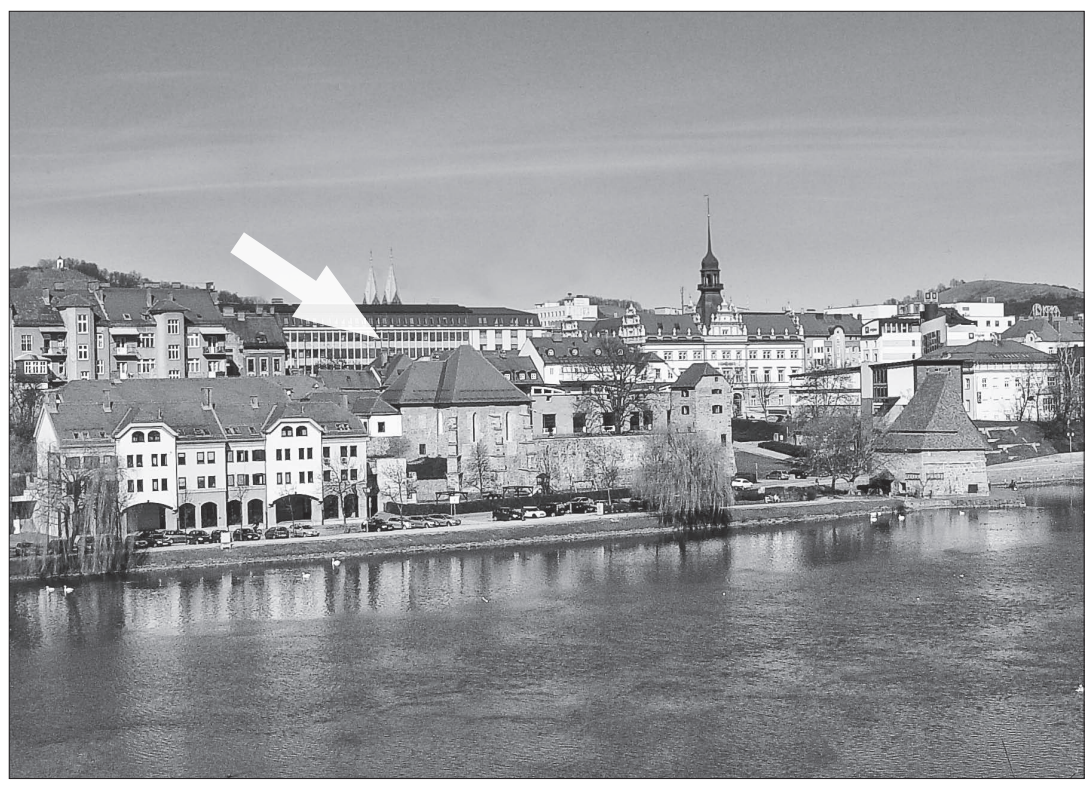

2. Maribor synagogue, a view on the southern part of the defense wall with the 'Jewish tower' in 2009

been viewed so far by Slovenian and international researchers as an exemplary achievement of the modern preservation doctrine, with the former director of the Synagogue cultural centre even stating in a recent article: "The renovation was successful and evaluated as a fine renovation example of the cultural and historical monument in the old city centre." ${ }^{14}$ But is it really?

Given that access to the extensive documentation files held by the IPCHS is now possible, ${ }^{15}$ that significant progress has been made in various research fields recently and that our current knowledge extends to more than 420 medieval synagogues and synagogue locations in areas populated with Ashkenazi Jews, ${ }^{16}$ it is finally time to reexamine and reevaluate the building and address the issues which were left open for future research. ${ }^{17}$ This article is thus not meant to provide answers to the unanswered questions linked to the synagogue itself, but to offer a retrospective look at its preservation attempts and finally its restoration in the 1990s. Answering these open questions would demand a thorough re-examination of the sources and IPCHS documentation, completion of the archaeological work interrupted because of lack of funds (with contemporary methodology),

relatively long duration of the work. In the second part of the preservation project, a separate research study on the synagogue was carried out by the Technical University of Graz and resulted in an excellent thesis. See Andrej ŠMID, Jüdisches Kulturzentrum, Synagoge, Architekturzentrum und drei Plätze, Graz 1998 (unpublished master thesis). Šmid carried out extensive research of the sources, even making 3D models of the interior. Unfortunately, without the necessary data, it was impossible to reconstruct any of the phases of the medieval building.

14 See Marjan TOŠ, Prekletstvo judovske skupnosti v Mariboru - 520 let po izgonu Judov iz mesta, Časopis za zgodovino in narodopisje, n. s. 52, 2016, p. 47. See also Rudolf KLEIN, Spirituality and Space, in: Rivka Dorfman, Ben-Zion Dorfman, Synagogues without Jews and Communities that Built and Used them, Philadelphia 2000, pp. 318-326. See also Marjan TOŠ, Mariborski Judje nekoč. Obnovljena nekdanja sinagoga danes, Signal. Letni zbornik Pavlove hiše, 2005/06, pp. 107-113.

15 I would like to sincerely thank Simona Menoni Muršič from the Maribor Regional Office of the IPCHS, for granting us access to the documentation (Fond Maribor - Sinagoga).

16 PAULUS 2007 (n. 1), pp. 56-58. The area of Ashkenazi Jews comprises Central and Eastern Europe.

17 The article is partly based on the research carried out by Anja and Janez Premk in 2015. The findings have already been presented in a pocket book issued in Slovenian by The Research Centre of the Slovenian Academy of Sciences and Arts (ZRC SAZU), France Stele Institute of Art History, Ljubljana, Slovenia. See Janez PREMK, Anja PREMK, Mariborska sinagoga, Ljubljana 2015 (Umetnine v žepu, 12). 
3. Ebenfurth, Austria, the city wall with the reconstructed entrance into the synagogue, 16 th century

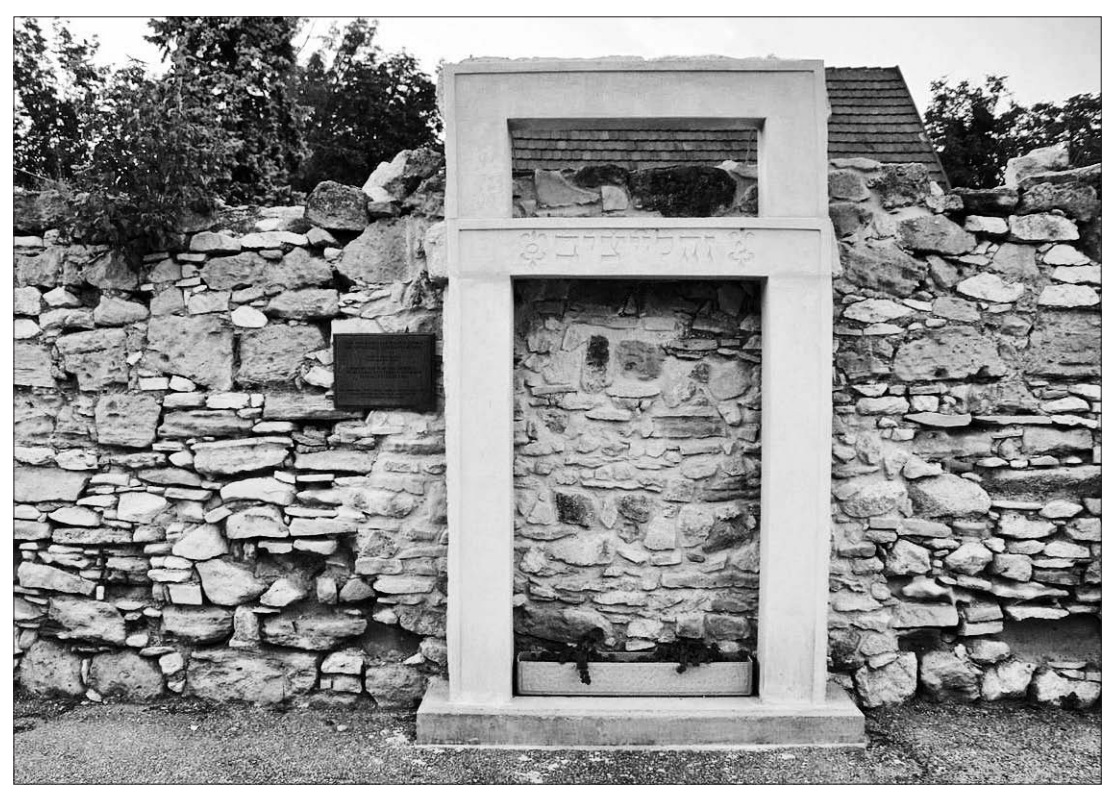

finding and documenting the architectural fragments and other remains of the building and carrying out a virtual scan (3D-CAD models) and finally, backed by the findings, virtually reconstructing the medieval building phase. I will focus on the preservation of the building in the 20th century, pointing out some of the highly problematic and questionable decisions made during restoration in light of recent advances in the research of Ashkenazi synagogue architecture.

\section{The Maribor Synagogue and its Wider Central European Context}

The location of Maribor synagogue in the heart of the former Jewish quarter, not far from the town market and a water source - the Drava River-is all but a solitary instance of such medieval urban topography (fig. 2). ${ }^{18}$ On the southern side the building abuts the medieval city wall, sitting close to its north eastern corner, similar to the former synagogue in Ebenfurth, Austria (fig. 3). ${ }^{19}$ The southern façade descends steeply to the level of the second terrace of the Drava River, while the platform of the northern façade is now elevated. The building is spatially significant in terms of length $(16.2 \mathrm{~m})$, width $(14.2 \mathrm{~m})$ and height, especially in relation to the surrounding buildings of the former Jewish quarter, located in the south-eastern section of the medieval town. ${ }^{20}$ The right bank of the Drava River offers a beautiful view of the medieval core, with the southern façade of the former synagogue marking the location of the Jewish quarter. Maribor synagogue can be

18 See Markus WENNINGER, Zur Topographie der Judenviertel in den mittelalterlichen deutschen Städten anhand österreichischer Beispiele, Juden in der Stadt (eds. Fritz Mayrhofen, Ferdinand Opll), Linz 1999 (Beiträge zur Geschichte der Städte Mitteleuropas, 15), pp. 81-117. For a vast literature on the topic of Jewish quarters see Birgit WIEDL, Jews and the City. Parameters of Jewish Urban Life in Late Medieval Austria, Urban Space in the Middle Ages and the Early Modern Age (ed. Albrecht Classens), Berlin-New York 2009 (Fundamentals of Medieval and Early Modern Culture, 4), p. 284, n. 46.

19 GLATZ 2013 (n. 12), p. 12. The early modern Ebenfurth synagogue also abuts a wall and is located in the northeastern part of the town.

20 Janez PREMK, Mihaela HUDELJA, Tracing Jewish Heritage. A Guidebook to Slovenia, Ljubljana 2014, p. 56. 


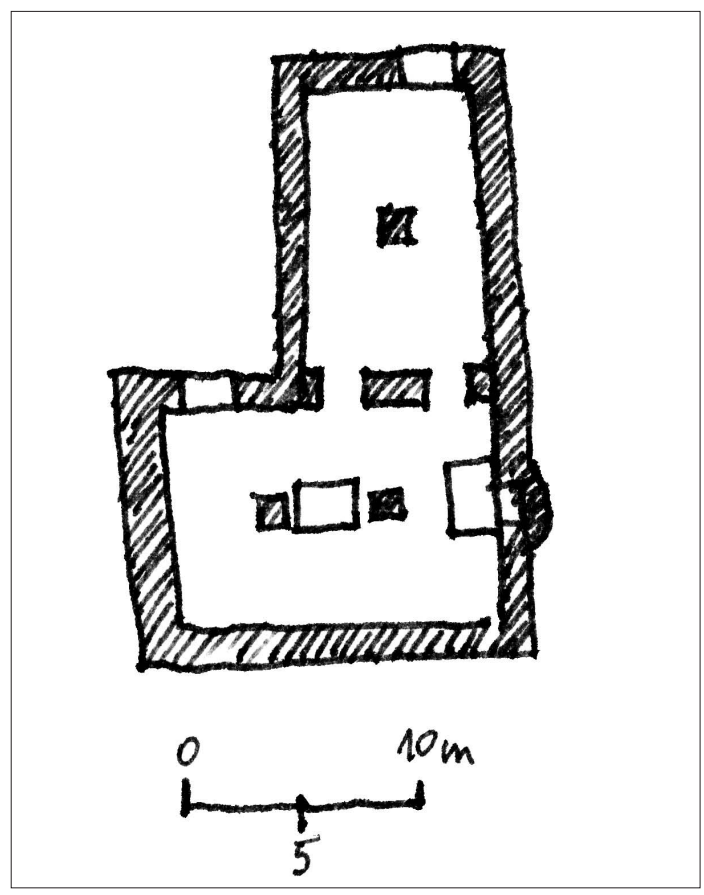

4. Worms synagogue, c. 1360, ground plan

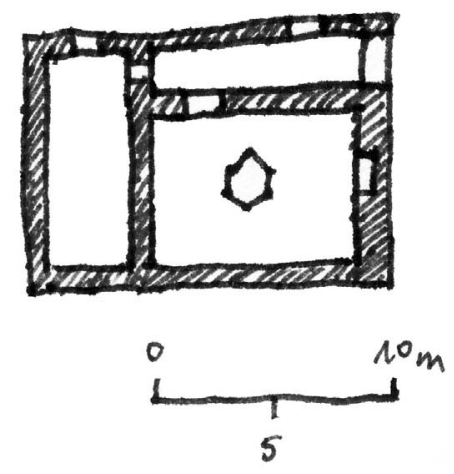

6. Sopron synagogue, c. 1300-1325, ground plan
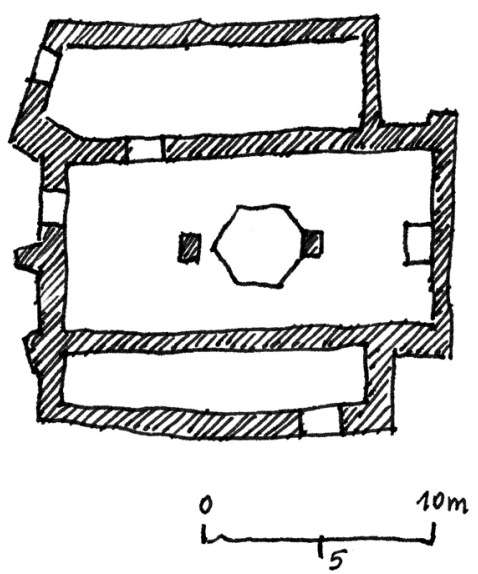

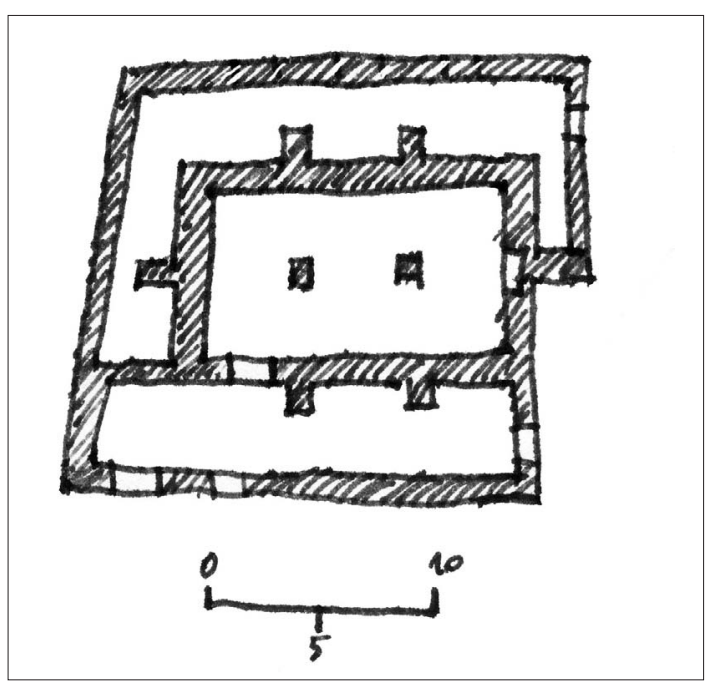

5. Altneuschul synagogue, Prague, c. 1300, ground plan

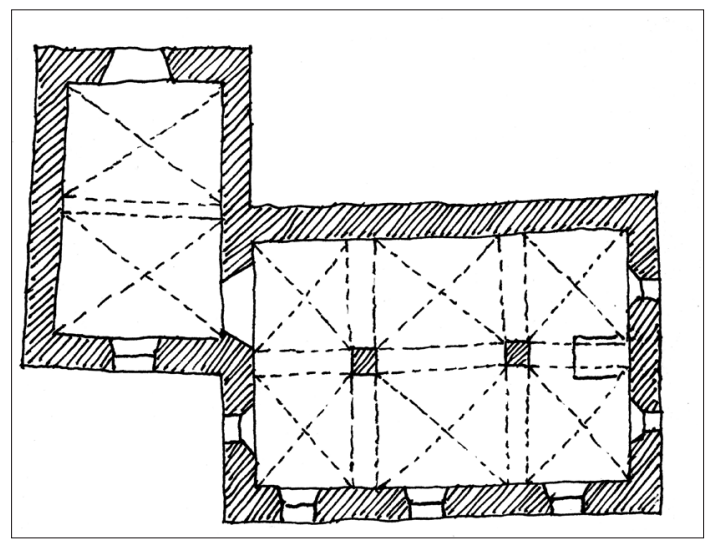

7. Maribor synagogue, ground plan of the second building phase, mid-14th century

8. Vienna synagogue, ground plan reconstruction of the second building phase, 14th century 
ranked among the larger medieval single-nave synagogues of Central and South-Eastern Europe. ${ }^{21}$ Given current knowledge on medieval synagogue or prayer hall locations in the territories settled by Ashkenazi Jews, as documented in the archives, the number of preserved or archaeologically traceable sites has radically declined..$^{22}$ As Simon Paulus states in his book on synagogue architecture in the Middle Ages, the following synagogue locations have been preserved: Worms (fig. 4), Speyer, Rufach, Erfurt, Altneuschul in Prague (fig. 5), Miltenberg, Kraków, both synagogues in Sopron (fig. 6), Maribor (fig. 7), and the buildings which are more or less intact: Strzegom, Korneuburg, Bruck a. d. Leitha, and Tulln. However, private synagogues included, there are many more buildings with a less identifiable function, which are occasionally traceable only through archival sources, historical mapping, depictions or archaeological excavations, as in the case of Maison Sublime in Rouen, Oppenheim, Oleśnica, Hainburg, Jawor, Vienna, Bratislava, Budapest and some presumed locations of prayer rooms. ${ }^{23}$ Sometimes several building phases are discernible.

In the last two decades, considerable progress has been made in the documentation, localisation, archaeological examination, virtual reconstruction and revitalisation of the medieval and early modern synagogue architecture of Austria. ${ }^{24}$ The densest network of medieval synagogues of the socalled Duchy of Austria is to be found in the region surrounding today's capital, Vienna, and other parts of Lower Austria. ${ }^{25}$ The former synagogues in Judenplatz in Vienna (fig. 8), Korneuburg, Tulln, Hainburg, Mödling stand out typologically. ${ }^{26}$ There are two additional synagogue buildings which could only be traced and virtually reconstructed through historic depictions: Klosterneuburg and Neunkirchen. ${ }^{27}$ While there is a single known synagogue location in Upper Austria attested to in documentation and through archaeological excavations in Linz, ${ }^{28}$ there are more historically traceable synagogues in the Austrian part of Styria and in Jewish communities closely connected to that of Maribor: Bruck an der Mur, Graz, Judenburg, Murau, Bad Radkersburg, Voitsberg and Hartberg. ${ }^{29}$ The first synagogue in Graz originated in 14th century and was active until 1438, when the community most probably suffered heavily during the anti-Jewish riots. When the Jews resettled in Graz in

21 See PAULUS 2007 (n. 1), pp. 331-332. The building dimensions often point to the eminence of the Jewish community.

22 PAULUS 2007 (n. 1), pp. 56-61. The real number of medieval synagogues must have been higher than 420 because many former Jewish communities do not have any traceable synagogue sites.

23 PAULUS 2007 (n. 1), pp. 56-57. See also The Bezalel Narkiss Index of Jewish Art, http://cja.huji.ac.il/browser. php? mode=main (accessed: 1 July 2018).

24 For the notable efforts made by Vienna and Graz universities, encouraging students in synagogue research, see above. The outcome is a series of theses on the architectural history of synagogues, a few even resulting in virtual reconstructions of the Jewish sites. Several more or less reliable virtual reconstructions have been made recently by the Vienna University of Technology, providing some new insights into the topic. See also KEIL 2006 (n. 1), p. 17, who mentions six wholly or partially preserved medieval synagogues in Austria.

25 PAULUS 2007 (n. 1), pp. 331-332, mentions the following historically traceable sites: Bruck an der Leitha, Eggenburg, Hainburg, Klosterneuburg, Korneuburg, Krems, Langenlois, Marchegg, Mödling, Neulengbach, Neunkirchen, Wiener Neustadt, Perchtoldsdorf and Tulln. For Vienna synagogue see also Heidrun HEIGERT, Die spätmittelalterliche Synagoge in Wien (13.-15. Jahrhundert), Judovski zbornik 2000 (n. 10), pp. 173-202.

26 See also GLATZ 2013 (n. 12), pp. 7-11; Jelena MALIC, Adaption der Synagoge „Rossmühle“ in Korneuburg, Wien 2015, pp. 14-17.

27 PAULUS 2007 (n. 1), p. 333.

28 PAULUS 2007 (n. 1), pp. 383-385.

29 PAULUS 2007 (n. 1), pp. 386-391. 
1447 , they most probably built another synagogue in a different location. ${ }^{30}$ Four medieval synagogues have been discovered in the archive sources of Austrian Carinthia. ${ }^{31}$

Also interesting is the continuity of the synagogue building practices in the early modern ages. As the Jewish Middle Ages lasted until the 17th century, this also is true for some post-medieval synagogues in Austria. In her master thesis, Sandra Glatz carried out a virtual reconstruction of the Oberwaltersdorf and Ebenfurth synagogues on the basis of a detailed study of similar buildings. She examined and compared individual characteristics such as the urban context, layout, design and alignment of the entrance, and the design of the windows on the east wall, etc. While she used Maribor synagogue after its reconstruction as an important reference point, ${ }^{32}$ her work has also shed light on some aspects of the Maribor synagogue and its interior design and equipment. Sometimes the only way to gain insight into the original appearance and interior spatial organisation of a building is to search for analogies. ${ }^{33}$

In the present territory of Slovenia, where the medieval Ashkenazi cultural sphere south of the Alps encountered the Roman-Italian world (economic ties with Venice and Northern Italy) and later the Sephardi world (Dalmatia), the following synagogue locations, besides Maribor, are mentioned in the sources: Ljubljana, ${ }^{34}$ Ptuj, ${ }^{35}$ Koper, ${ }^{36}$ and indirectly Piran.${ }^{37}$ In the case of Ljubljana and Ptuj in particular, the location of the former synagogues is indicated in the sources and now occupied by residential buildings. Non-intrusive archaeological examination of the basement and foundations could reveal the ground plan or at least possible structural remnants. ${ }^{38}$ Additional synagogue buildings or prayer rooms might have existed in other medieval Jewish settlements in Slovenia, such as Celje and Slovenj Gradec. ${ }^{39}$

30 PAULUS 2007 (n. 1), pp. 387-390. The second synagogue probably existed at the present location of Fischer-vonErlach-Gasse 2 and might have been turned into a St Mary's chapel.

31 PAULUS 2007 (n. 1), p. 391, n. 91. It should be mentioned that the Friesach synagogue owned by the Salzburg archbishops might prove relevant for research on Ptuj synagogue. It is the only synagogue in Carinthia with some preserved remains discernable within a residential dwelling. If the assumption by Markus Wenninger that the synagogue already existed in 1124 is correct, then it should be counted among the earliest in the area. Other synagogues include St. Veit an der Glan, Villach, and Völkermarkt, although additional synagogues might have existed in other Jewish settlements.

32 GLATZ 2013 (n. 12), pp. 12-14.

33 Sandra Glatz also made 3D models of the interior elements. Her work would provide a good reference point for visual reconstructions of the Maribor synagogue.

34 For the Ljubljana synagogue, see Vlado VALENČIČ, Židje v preteklosti Ljubljane, Ljubljana 1992, p. 11. See also Mihaela HUDELJA, Judje v Ljubljani od 13. do 19. stoletja, Etnolog, 4, 1994, p. 123.

35 In a document dating 1405, the Judengasse and Ptuj synagogues are mentioned in Ptuj. See Boris HAJDINJAK, Judje srednjeveškega Ptuja, Slovenski Judje. Zgodovina in holokavst. Pregled raziskovalnih tematik (eds. Irena Šumi, Hannah Starman), Maribor 2013, pp. 65-67.

36 In Koper, the synagogue was situated just a few steps from the central square on the west side of Čevljarska Street (Calegaria), according to a chronicle of 1885 . See Capodistria, 19/14, 16 July 1885, p. 105. There used to be a plaque on the main façade of the house, attesting to its history. The house is supposed to have been situated on the site of today's Čevljarska Street 8.

37 In Piran, the contract signed in 1484 states the right to a synagogue, meaning the Jews had religious autonomy and a local rabbi. But the synagogue could also have been erected in a private house simply as a prayer room. See Janez PERŠIČ, Židje in kreditno poslovanje v srednjeveškem Piranu, Ljubljana 1999 (Historia. Znanstvena zbirka Oddelka za zgodovino Filozofske fakultete Univerze v Ljubljani, 3), p. 91.

38 Any more in-depth archaeological interventions might be obstructed by the real-estate owners, not aware of its cultural and historic impact. This is often the case even when buildings have protected monument status. Applying non-intrusive techniques might provide sufficient evidence for virtual reconstruction of the sites.

39 See Klemen JELINČIČ BOETA, Judje na Slovenskem v srednjem veku. Judje na Koroškem, Štajerskem, Kranjskem, Goriškem, v Trstu in Istri v srednjem veku do izgonov v letih 1496-1515, Ljubljana 2009. 
9. France Stele's field notes with sketches of Maribor synagogue,

UIFS ZRC SAZU, Ljubljana

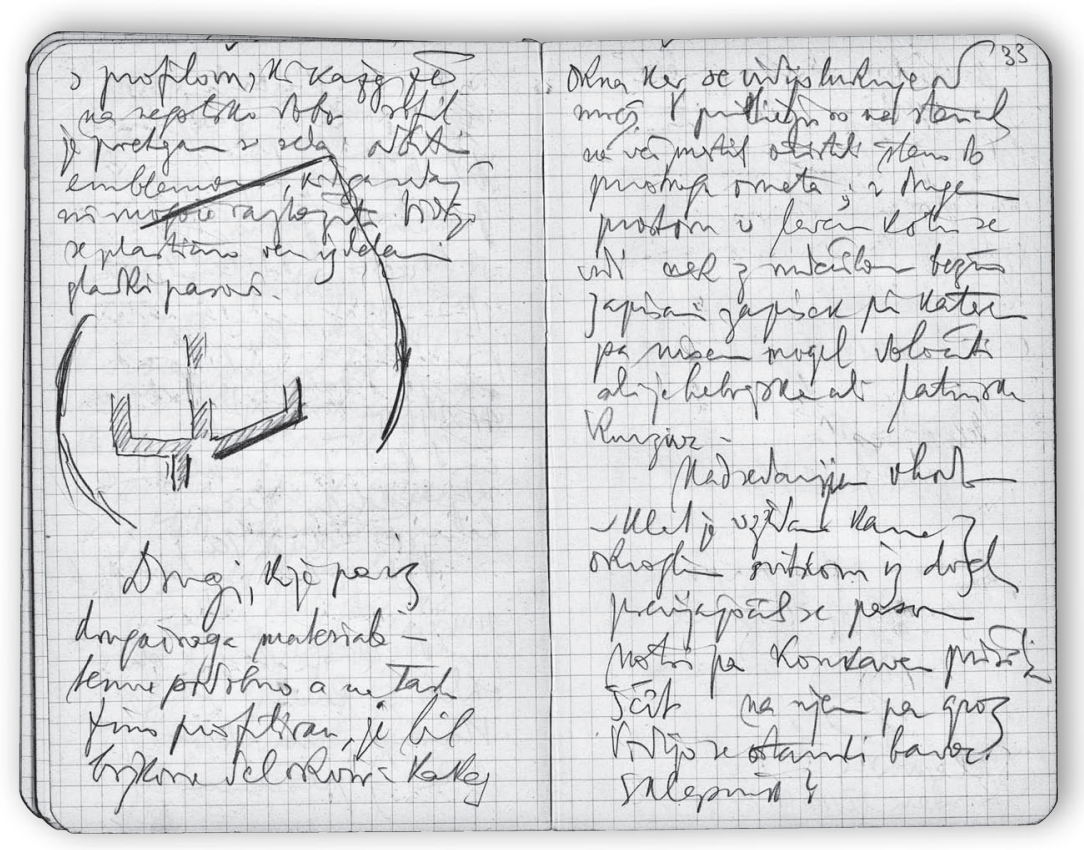

\section{The First Professional Documentation and Preservation Measures in the 20th Century}

The history of the Maribor synagogue, as recorded in the written sources, can be divided into three phases: the Jewish phase, when the building was used as a synagogue (until 1497), the Christian phase (from 1497 until 1784), when the synagogue was turned into the Church of All Saints, and the last period of its secular usage (from 1785 onwards). ${ }^{40}$ Even during secular usage, the feeling of the building's past use as a synagogue is still very much present. In 1926 the building belonged to the Maribor municipality, which launched the first professional restoration works on it.

France Stele, a pioneer of Slovene art heritage protection and the head of the monument protection office, monitored the work. His surviving archive and correspondence reveal several details regarding the renovation. In a letter from 13 March 1926, Franc Kovačič, president of the Maribor Museum Society, informed Stele about the renovations. He pointed out that there were some beautiful pieces of fluted shafts that once carried the Gothic ribbed vault, and he asked the mayor to carefully inspect the building and dig below the existing floor in order to find the synagogue's original floor. He also mentioned the interest of Zagreb Jews in the building. ${ }^{41}$ In another letter from 23 March 1926, France Stele informed the municipality of having inspected the extracted remains of the former Jewish synagogue. The original ground plan was ascertained, as was the basic architectural appearance of the interior, on the basis of the consoles of the Gothic vault. There were three stones attached to the outside wall, which France Stele with almost absolute certainty identified as the vault's keystones, and which he was able to meticulously describe (fig. 9,

40 PREMK, PREMK 2015 (n. 17), p. 22. The synagogue is mentioned three times in the written sources: in 1354, 1431 and 1477. See also MIKUŽ 2000 (n. 10), p. 169.

41 Information and Documentation Centre for Heritage at the Ministry of Culture (INDOK Centre), Fond Maribor Sinagoga. 


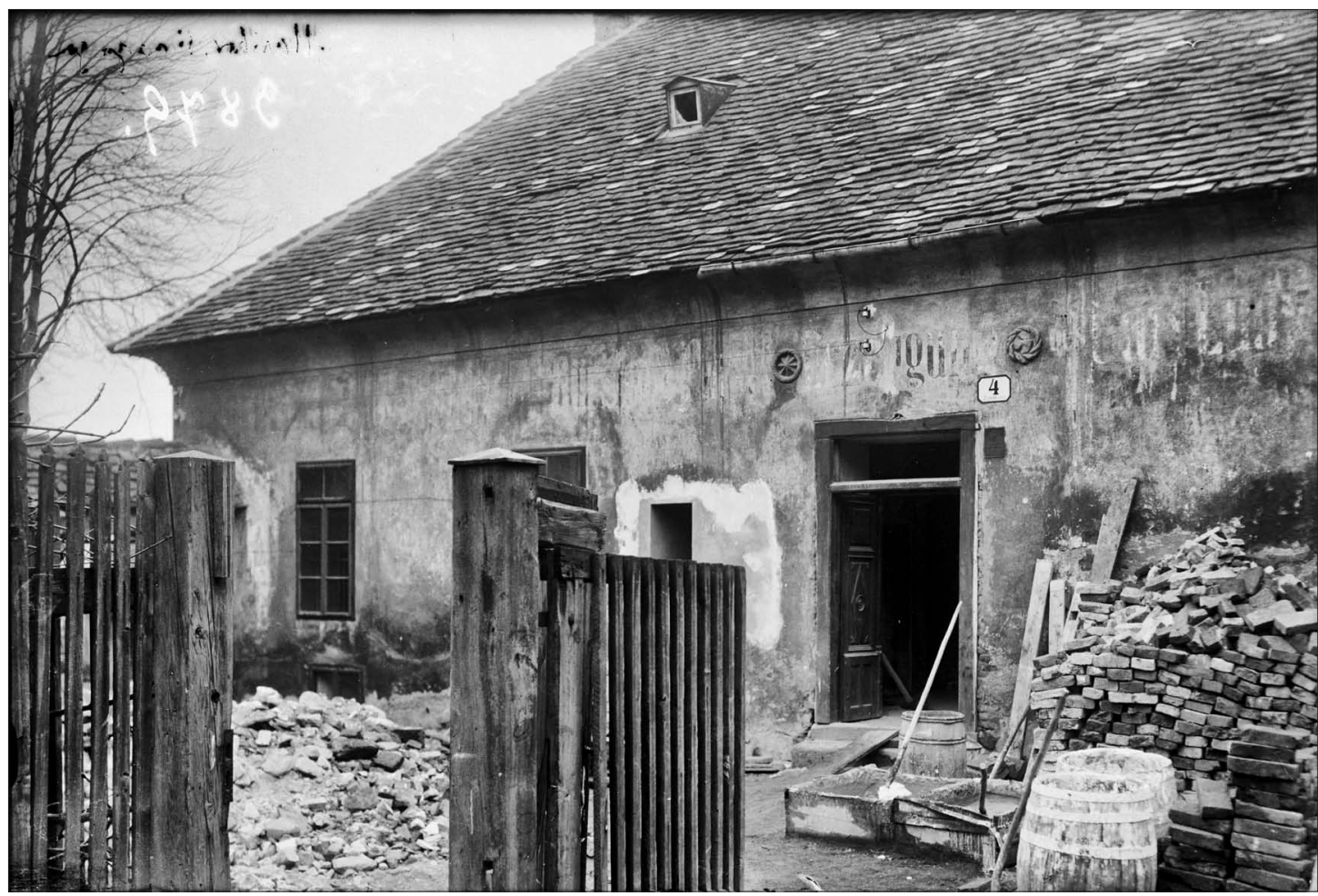

10. France Stele's photograph of the northern facade of Maribor synagogue during the renovation works in 1926

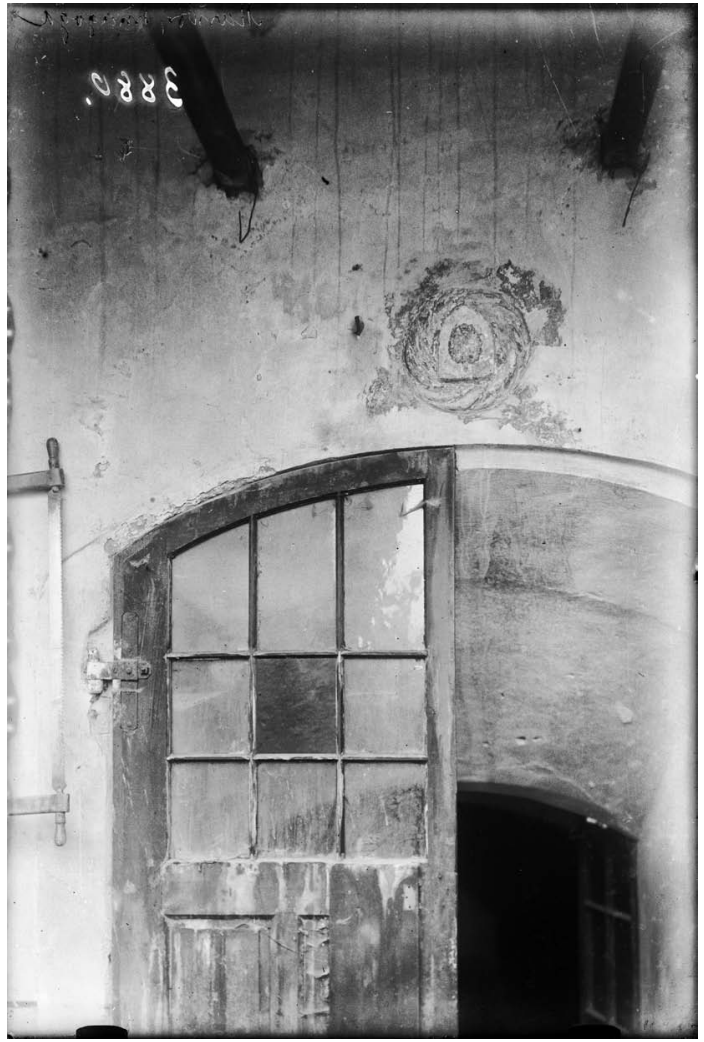

11. Keystone with a motif of grape, basement entrance at the eastern façade of Maribor synagogue

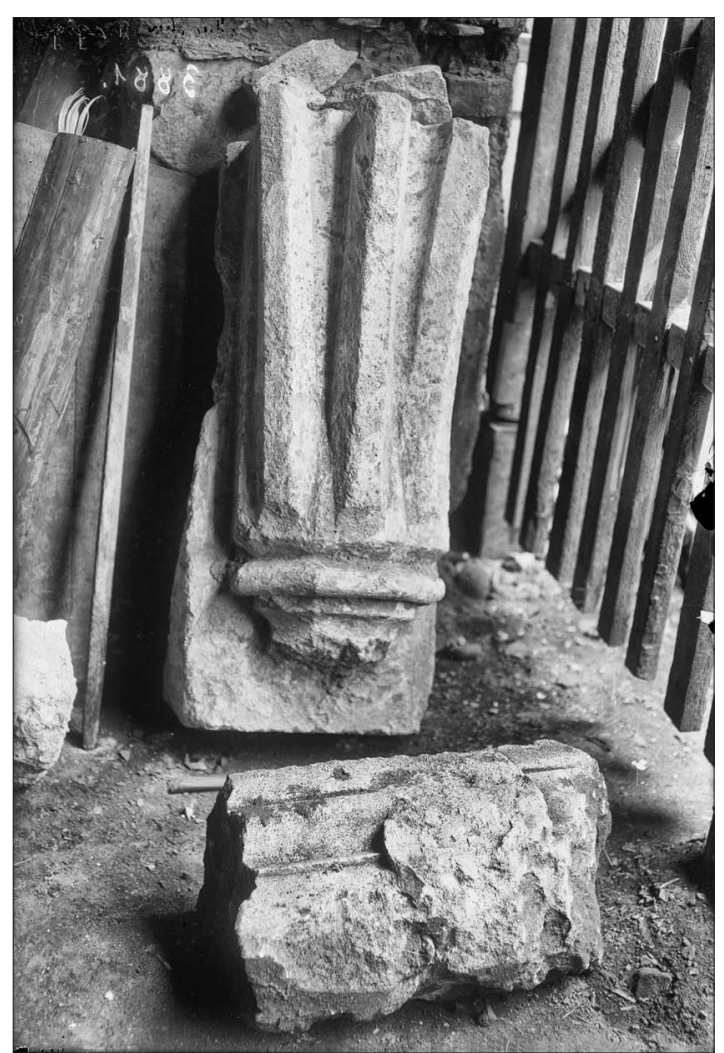

12. France Stele's photograph of a fragment of ribbed linear profiled console, c. 1926 


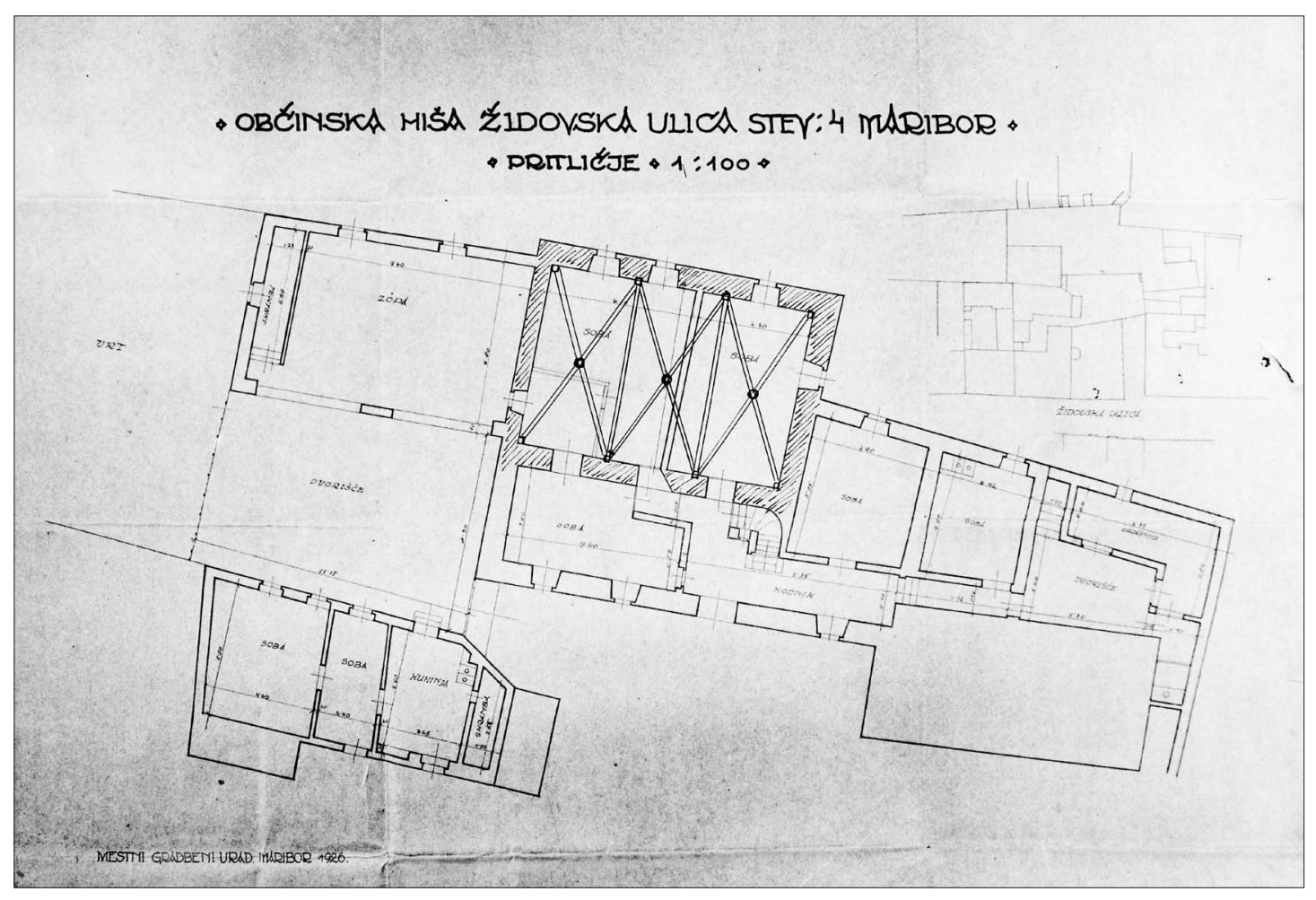

13. A ground plan of Maribor synagogue with France Stele's drawing of a three-bay vault, INDOK Centre, Ljubljana

10). ${ }^{42} \mathrm{He}$ was right in his assumption, since all three of the keystones are preserved and can be identified easily in the two photos he took (fig. 11). ${ }^{43} \mathrm{He}$ also reported that the findings, consisting of: one console with the beginning of the ribs (fig. 12), two stones, belonging to the window or door frame and one stone with the Hebrew letter aleph, were in the possession of Maribor Museum. ${ }^{44} \mathrm{At}$ the end of the report, he stressed the importance of the findings for Maribor, since they enabled a complete reconstruction of the building, but also (the importance) for the history of the Jews in our area. ${ }^{45}$ During the renovation work, eight consoles were identified, four on each of the two sides of the interior wall, which led him to conclude that the interior of the synagogue must have been divided into three bays, vaulted with gothic cross ribs. Stele sketched his vision of the vault into the ground plan drawn up during the construction works in 1926 (fig. 13), ${ }^{46}$ which we managed to

42 France Stele Institute of Art History, ZRC SAZU (UIFS ZRC SAZU), France Stele's field notes, notebook XL, fol. $33 \mathrm{v}-34$. Stele even specified the exact position: "Above the entrance into the basement today a stone is built in with a round coil consisting of two intertwining girdles, in the middle a concave pointed shield, and a grape on it. / ... / Above the main entrance into the building two stones are built in: the left represents a relief rounded coil, wound more tightly than the second one mentioned; a sculpted 8-pointed star is inside the coil. The right second one has a thicker coil made of two girdles; inside there is a turban girdle made of rounded belts." See also France STELE, Varstvo spomenikov, Zbornik za umetnostno zgodovino, 6/2, 1926, p. 114. During the preservation works in the 1990s, only two keystones were found on the outside wall. See MIKUŽ 2000 (n. 10), p. 164.

43 The photos showing the keystones before they were detached from the plaster. Two of the keystones are above the entrance on the northern wall and the third keystone with a grape at the entrance into the basement of the building from the eastern side, at the time still occupied by an attached residential house.

44 Unfortunately, it was not possible so far to locate these elements in the Maribor Regional Museum.

45 INDOK Centre, Fond Maribor - Sinagoga.

${ }^{46}$ INDOK Centre, Fond Maribor - Sinagoga. The ground plans were issued by the City Construction Office in Mari- 


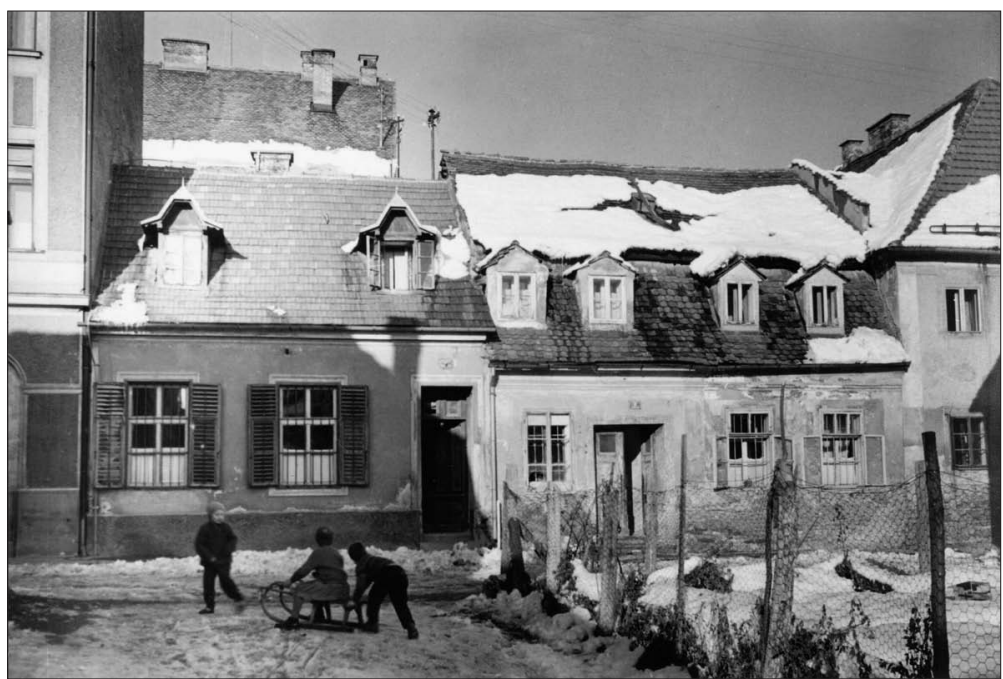

14. Residential houses on 3 and 5 Židovska Street, Maribor, 1962/63

locate with the two photographs in the INDOK Cultural Heritage Centre. ${ }^{47}$ The older plans, the first from 1861, the addition of a boiler room to the existing building complex of a cotton wool plant, and the second from 1877, an adaptation into a residential house and workshop, indicate that the ownership of the synagogue is also interesting. ${ }^{48}$ The plans reveal that the building was the property of a single owner: part of the synagogue building on the north-eastern side, then in secular use, was a house; on the western side was the living area with two rooms, and a yard with a workshop. If the ownership structure remained unchanged, it is evident that it might have been used as a curates' house and before that a residential house for a Jewish dignitary, perhaps a Rabbi, Shamash or Hazzan. ${ }^{49}$ There were also two lavatories, only accessible from the yard, which is also useful information in regard to the medieval layout of the synagogue's surroundings. As recorded in literature, a substantial section of land beside the synagogue was divided into a mikweh, a hospice, a yeshiva-Talmudic school, and public lavatories (bet kise). ${ }^{50}$

Thanks to the initial involvement of France Stele and his student Jože Curk in particular, who also became a leading Slovenian conservator, the building was entered into the Register of Cultural and Art

bor (Mestni gradbeni urad Maribor) in 1926. The problem of his three-bay division of the inner space theory is that he did not know about the angle of the intersecting ribs of the keystones because they were hidden under the plaster.

47 The ground plan and the two pictures were probably not known to the preservation staff. It is accessible at the Information and Documentation Centre for Heritage at the Ministry of Culture.

48 PREMK, PREMK 2015 (n. 17), p. 31. The plans are held in the Maribor Regional Archives; SI PAM/0057, Okrajni urad Maribor (1854-1868), 118/7, fol. 538; SI_PAM/0011, Uprava za gradnje in regulacijo Maribor (1840-1963), Gorkega ulica 25A, TA 421. See also Mija OTER GORENČIČ, Sinagoga, 2014, http://www.mariborart.si/spomenik/-/article-display/sinagoga (accessed: 15 June 2018).

49 PREMK, PREMK 2015 (n. 17), p. 34. It was unusual for an allotment to change its ownership structure unless there was substantial building intervention. Soon after the expulsion of the Jews from Maribor in 1497, the building was converted into the Church of All Saints by Bernardin and Barbara Drucker, a town judge and one of the richest wine and money speculators, and his wife. They set up a benefice in the former house of the rabbi, and endowed it richly. The Church of All Saints is mentioned several times in diocese visitations. It existed until the mid-16th century, when the benefice was disbanded and the church began to deteriorate. See Cerkvene zadeve, Slovenski gospodar, 7/31, 30 July 1873, p. 248.

50 See Simon PAULUS, Im Spiegel zeitgenössischer rabbinischer Responsen, David. Jüdische Kulturzeitschrift, http:// davidkultur.at/artikel/im-spiegel-zeitgenossischer-rabbinischer-responsen (accessed: 17 January 2018). 


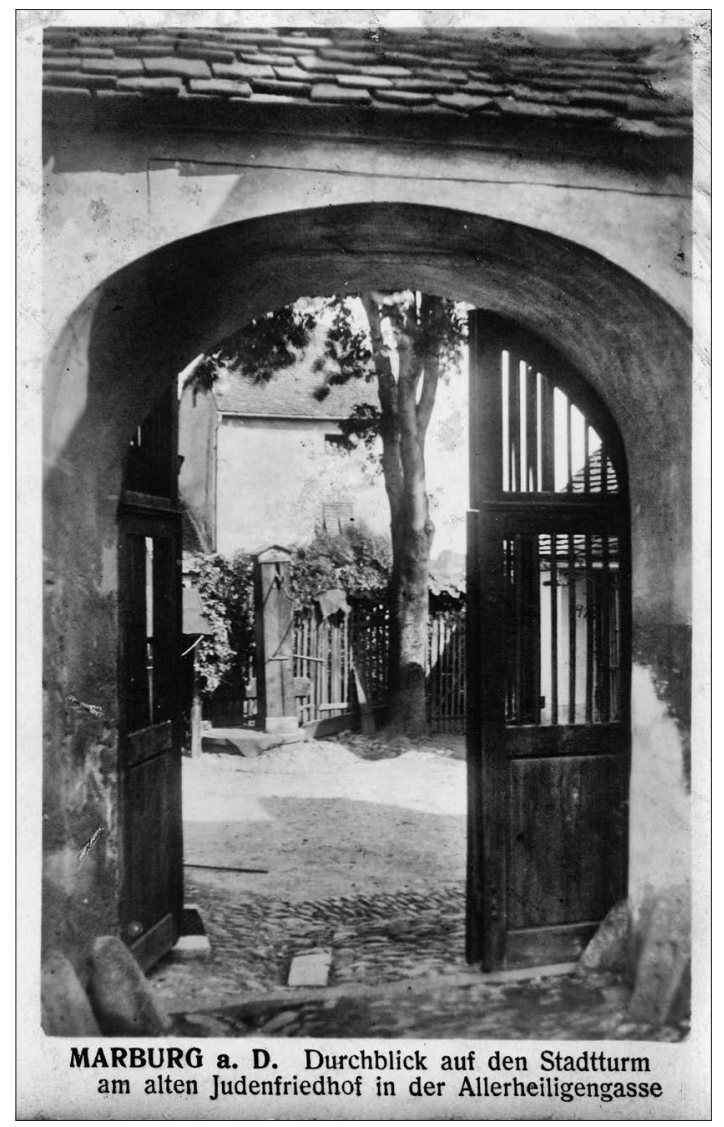

15. The Jewish tower next to the old Maribor Jewish cemetery, c. 1915
Monuments on 27 November $1964 .{ }^{51}$ As the director of the newly established Institute for Monument Protection Maribor (1959), Curk initiated the systematic documentation and research of old architectural heritage in Maribor and attempted to preserve the most endangered sites. As he granted them special status of (legally) protected monuments, he deserves credit for his involvement in saving the synagogue as well as most of the old buildings on the eastern side of Vetrinjska Street and the buildings on Židovska Street. ${ }^{52} \mathrm{He}$ was aware that typical houses, such as the two preserved buildings at 3 and 5 Židovska Street-with modified facadesand other houses of the medieval Jewish quarter originally comprised of a single floor with three window axes at most overlooking the street and a medieval core at least in their foundations (fig. 14). His appreciation for the historic building is further revealed in its inclusion in the presentation of the twelve most important construction projects in Maribor. ${ }^{53}$ His reports and articles described the building and presented the findings of previous preservation attempts as well as tracing its history. Unfortunately, he frequently did not reveal his sources, which were partly based on historic records and existing literature, partly on on-site findings and preservation re-
. Missing citations of course cause problems for sults, or were sometimes simply his own deductions. Missing citations of course cause problems for based on solid fact and evidence. The only way to resolve such cases is with a thorough examination of the older literature and quotations at source. Sometimes the statements are deliberately obscured in order to hide uncertainties, which of course always exist when dealing with such complicated matters as the historic reconstruction of a medieval synagogue. While this may be seen as a (minor) shortcoming in Curk's pioneering work on Maribor synagogue, it is harder to understand the lack of citations in the reports of the professional staff involved in the actual reconstruction of the building in the 1990s. ${ }^{54}$

51 In 2015 it was categorized as a monument of state importance, with the evidence number 6253 . See the Register of Slovene cultural heritage, http://rkd.situla.org/ (accessed: 23 July 2018).

52 Jože CURK, Urbano-gradbena in komunalna zgodovina Maribora, Kronika. Časopis za slovensko krajevno zgodovino, 31/2-3, 1983. See Branko VNUK, Ob devetdesetletnici Jožeta Curka, Zbornik za umetnostno zgodovino, n. s. 50, 2014, pp. 151-152. Today only a part of the former Jewish quarter is discernible: around Židovski Square (Jewish square), Židovska Street and Ključavničarska Street. There were about 20 houses overall in the Jewish quarter. The Jewish population amounted to about 150. For this assessment I am indebted to Boris Hajdinjak.

${ }^{53}$ Jože CURK, Oris 12 najpomembnejših gradbenih objektov v Mariboru I, Časopis za zgodovino in narodopisje, $\mathrm{n}$. s. 24/1, 1988, pp. 119-145; Jože CURK, Oris 12 najpomembnejših gradbenih objektov v Mariboru II, Časopis za zgodovino in narodopisje, n. s. 25/2, 1989, pp. 222-224.

54 This is less important in the case of indirect or minor issues which are not truly related to the core of the problem, but should not be the case when the evidence is vital for decision-making. 


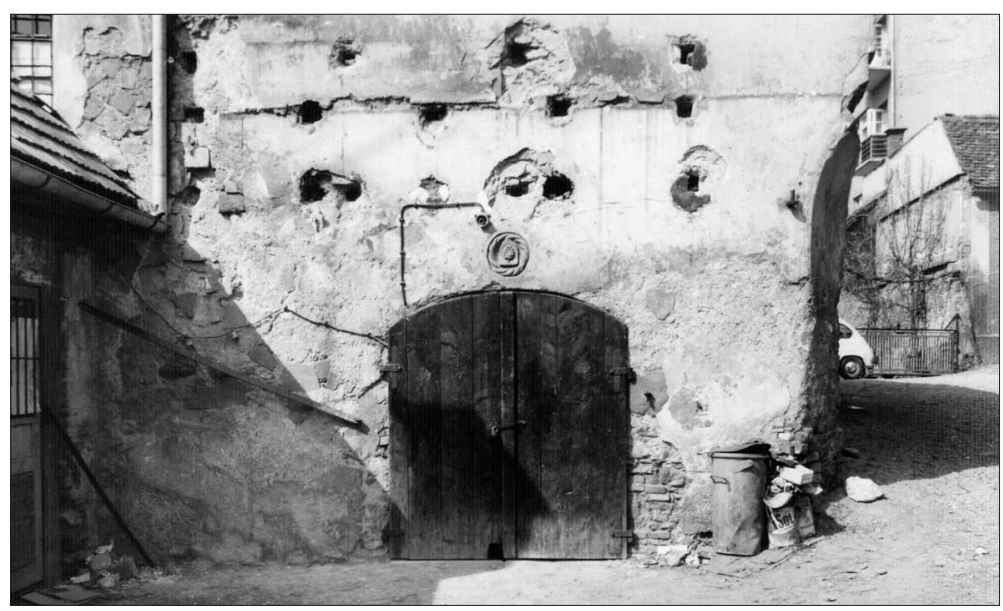

16. Eastern façade with the grape keystone above the basement entrance, April 1972, detail

It is common practice to point out any major issues und uncertainties encountered during a restoration, approaches to dealing with them and how they were ultimately resolved.

In a short report on Maribor synagogue in 1966, Jože Curk wrote: “The Jewish synagogue encompassed the whole space, supported by twelve consoles and four central columns, and carried by nine cross-rib vaults with relief consoles" ${ }^{55} \mathrm{He}$ might have been referring to the late-baroque vaults resting in the lower floor on two pillars, but definitely not four, while he had no proof to support his claim of twelve consoles. The archaeologist Pahičs's comments on the Jewish tombstone findings in the same review is more revealing. He mentions two medieval Jewish cemeteries, one unquestionably besides the synagogue and the second one presumably on Strma Street (fig. 15). ${ }^{56}$ Curk provides a much more profound analysis of the synagogue in 1989 in his description of the twelve most important buildings in Maribor, where he also systematically describes the interior and again tries to determine the appearance of the medieval interior with a completely different theory. ${ }^{57}$

His confirmation of the three keystones built into the façade, documented also by Stele, is hugely important. He even provides a description: "Built into the exterior are three round, coiled keystones, among them one decorated with a grape (fig. 16), the second one with an eight pointed star and the third one with a windmill, whereas its' inner eastern wall maintains a few spolia." ${ }^{38}$

$\mathrm{He}$ argues that it is difficult to imagine the synagogue development today because of the high plastering. It was, as he proposes, a simple, square, south oriented building, covered with a foursided roof, which was (assuming from the profile of the ribs) equipped with a central column and four cross-rib vaults. ${ }^{59}$ It is very difficult even to imagine how such a space might have looked, but

55 Jože CURK, Urbanistično-gradbeni zgodovinski oris I, Časopis za zgodovino in narodopisje, n. s. 2, 1966, p. 71: "Židovska sinagoga je obsegala enoten prostor, ki ga je nosilo 12 konzol in 4 osrednji stebri, pokrivalo pa 9 križnorebrastih obokov z reliefnimi sklepniki.«

56 Stanko PAHIČ, Arheološko raziskovanje v Mariboru, Časopis za zgodovino in narodopisje, n. s. 2, 1966, pp. 22-23, n. 25. Based on the quotations of Muchar and Janisch, Pahič also mentions the former Jewish tombstones being reused as spolia.

57 CURK 1989 (n. 53), p. 224. He continues by mentioning the organisation of the interior, which corresponded to the times of Esra-a Tora arch on the eastern side and a special, separated part for women on the western side.

58 CURK 1989 (n. 53), p. 223: »Na zunanjščini sinagoge so vzidani 3 okrogli, s svitki oviti sklepniki, katerih enega krasi grozd, drugega osemrogelna zvezda in tretjega vetrnica, medtem ko hrani njena vzhodna stena z notranje strani nekaj spolij."

59 CURK 1989 (n. 53), p. 224: »Danes je predstava o razvoju sinagoge težje dojemljiva zaradi visokih nasutij okoli nje. Ker njeno zemljišče proti jugu visi, se je stavba že ob nastanku s severno steno vkopala v tla, kot to dokazuje zazidan prvoten 


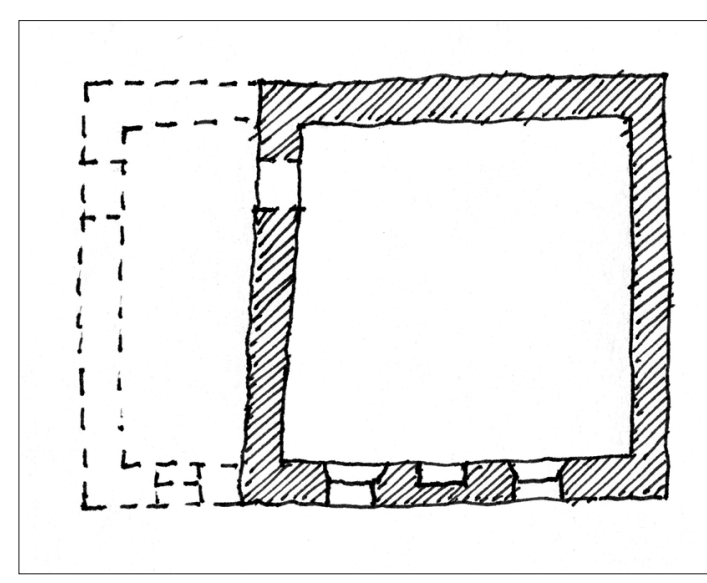

17. Ground plan reconstruction of the oldest phase of Maribor synagogue

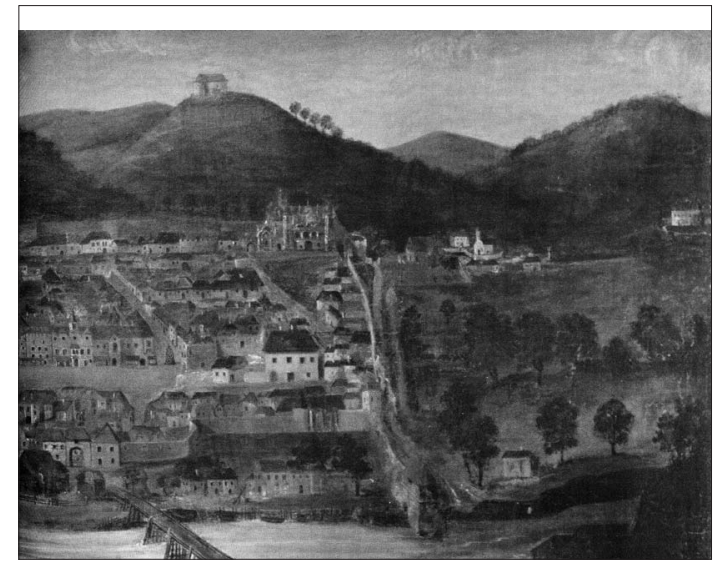

18. Townscape of Maribor, c. 1657,

Steiermärkisches Landesarchiv, Graz, detail

19. The Jewish tower in Maribor,

September 1972

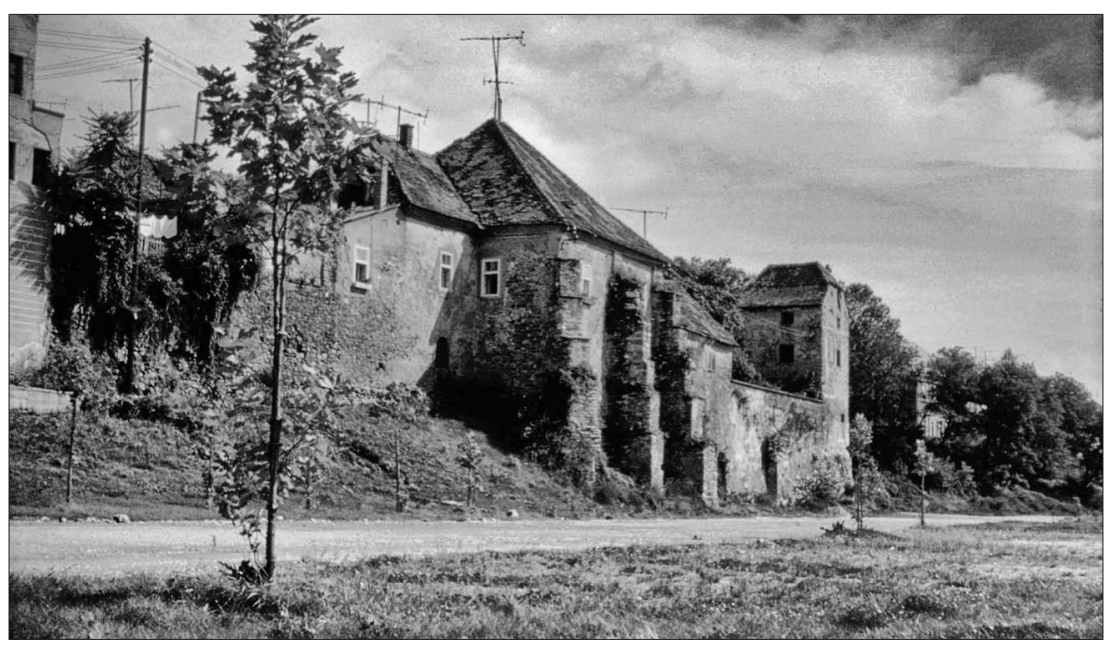

what is really significant is a) the orientation towards the south and b) division by a single column. As demonstrated in the book on Maribor synagogue, the archaeological excavations support the notions of a square ground plan and the southward orientation of the earliest phase of the building (fig. 17). ${ }^{60}$ Curk also mentions several early modern depictions of the synagogue, then already turned into a church. He saw a saddle roof in the earliest of these, dated 1657, and a high hip roof on the later ones (fig. 18). ${ }^{61}$ This is very important for understanding the appearance of the exterior. We suggest that the original synagogue building really did have a gable roof, as in the first depiction, and not a hip roof. ${ }^{62}$ He then continues with the building history until its secularisation in the 19 th century and concludes that in spite of the losses resulting from the modifications, transforming the synagogue into a seemingly insignificant building, it still preserves the picturesque south exterior and an important historical message, and is most worthy of revitalisation (fig. 19). ${ }^{63}$

vhod vanjo s trga. Bila je preprosta, približno kvadratasta, ravno krita, proti jugu obrnjena stavba, pokrita s štirikapno streho, ki so jo v 1. četrtini 15. stol. (po profilu reber sodeč) opremili z osrednjim slopom in 4 križnorebrastimi oboki.«

60 PREMK, PREMK 2015 (n. 17), p. 54.

61 CURK 1989 (n. 53), p. 224.

62 PREMK, PREMK 2015 (n. 17), p. 29. See Jože CURK, Primož PREMZL, Mariborske vedute, Maribor 2004, pp. 16, $18,66$.

${ }_{63}$ CURK 1989 (n. 53), p. 224. See also CURK, Viri za gradbeno zgodovino Maribor do 1850, Maribor 1985; Jože CURK, Maribor. Vodnik po mestu in bližnji okolici, Maribor 2000. 


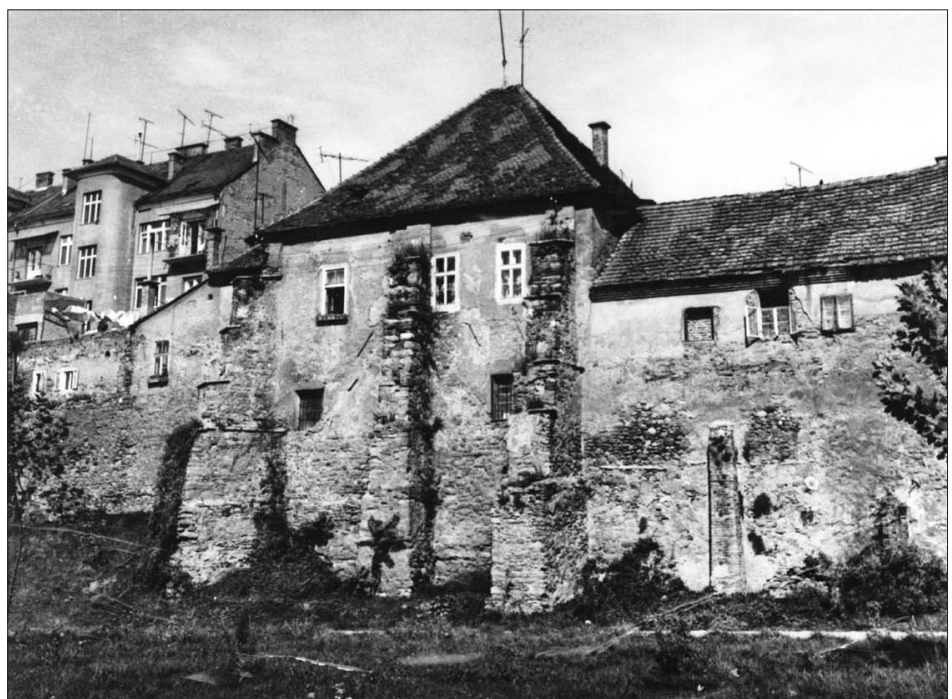

20. Southern façade of Maribor synagogue, the state before the 1992 renovation

\section{The Works Carried Out between 1992 and 1999:}

\section{Reconstruction, Renovation, Reinterpretation or Reinvention?}

Although the initial stages of the renovation of the building in the 1990s were far from reassuring, basic preservation measures had already been taken by Stele and Curk, as previously demonstrated. There also was some historic and contemporary evidence and research by historians such as Puff, Travner and Mlinarič, and some literature on medieval synagogues and their typology. ${ }^{64} \mathrm{After}$ carrying out the preliminary urban and historic research, ${ }^{65}$ the basic preservation guidelines were set: to preserve and present all the urban features of the area, which besides the synagogue included the residential area dating to the same period, the space occupied by the alleged Jewish cemetery between the synagogue and the Jewish tower, the plateau on the northern side and the Jewish ritual bath (mikweh) below the walls, level with the Drava river. ${ }^{66}$ The decision to reconstruct the medieval phase of the building was an extraordinary and daring move during the infancy of the Slovenian state, and the funding for detailed research far from guaranteed. Nevertheless, the groundbreaking work was initiated and the inhabitants, fond of the long and rich architectural history of the city, eagerly awaited its results (fig. 20).

From today's perspective, a huge disadvantage in continuing research on the building and resolving remaining questions is that it is extremely difficult to trace the sequence, position and exact number of findings from the IPCHS reports. Also, only a few architectural elements (such as keystones) belonging to the medieval and early modern periods, which would provide the basis for 3D CAD projections, are displayed in the synagogue, while others are missing, although hopefully preserved in the repository of the IPCHS. The only reliable source is the extensive photographic documentation and archival fond of the project (figs. 21-23). ${ }^{67}$

64 Rudolf Gustav PUFF, Marburg in Steiermark. Seine Umgebung, Bewohner und Geschichte, Gratz 1847; Vladimir TRAVNER, Mariborski ghetto, Kronika slovenskih mest, 2/2, 1935, pp. 154-159; Jože MLINARIČ, Mariborski Židje $v$ zadnjih desetletjih pred izgonom iz mesta, njihov izgon in sledovi, Maribor 1996.

65 Janez MIKUŽ, Maribor, Varstvo spomenikov, 33, 1991, p. 305.

66 MIKUŽ 2000 (n. 10), p. 161.

67 IPCHS, Maribor Regional Office, Fond Maribor - Sinagoga. 


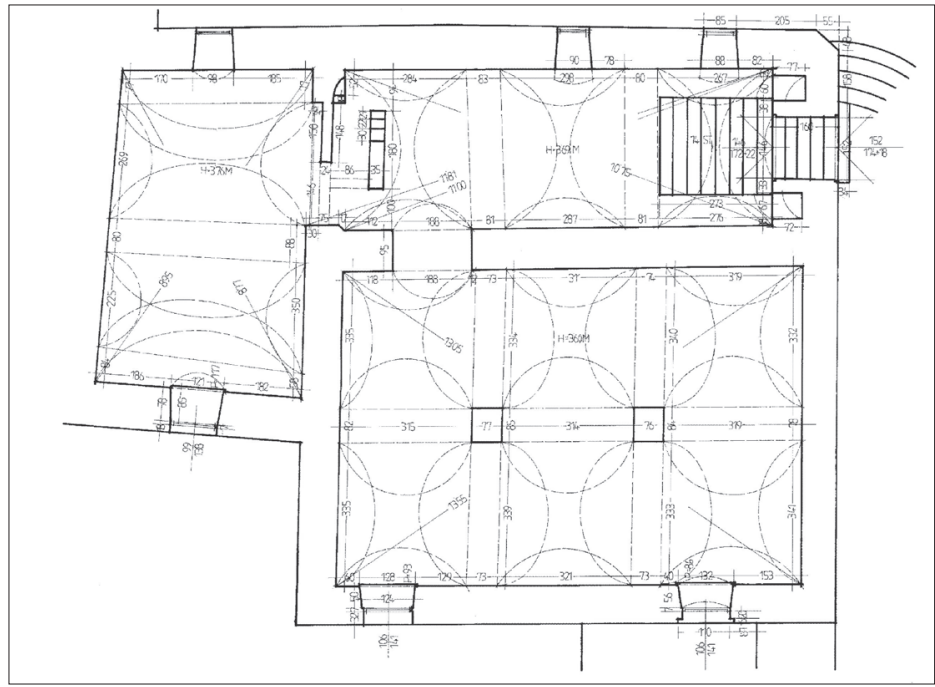

21. Maribor synagogue, ground plan before the 1992 renovation

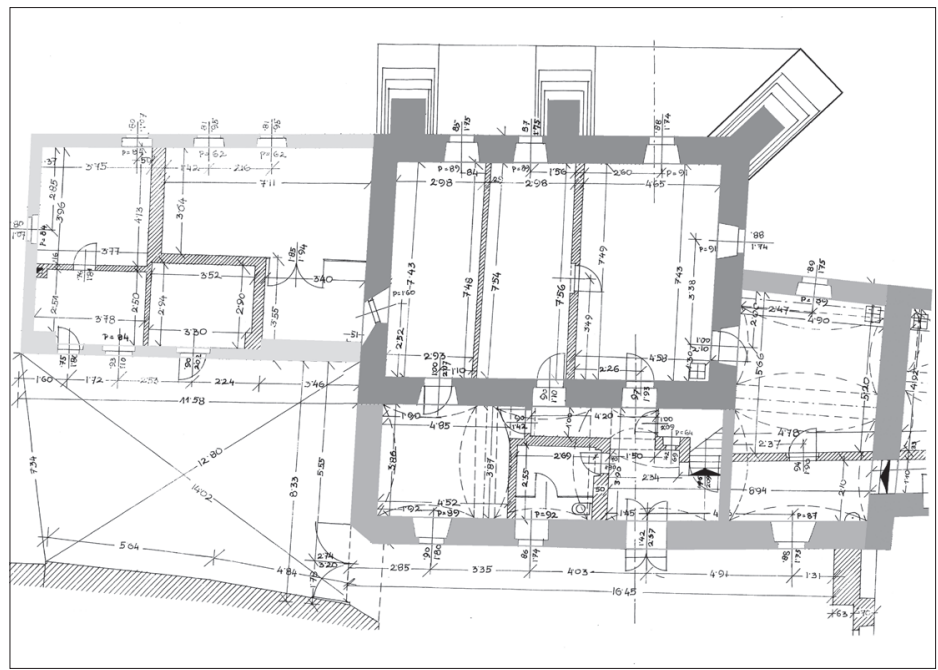

22. Maribor synagogue, plan of the basement, 1960

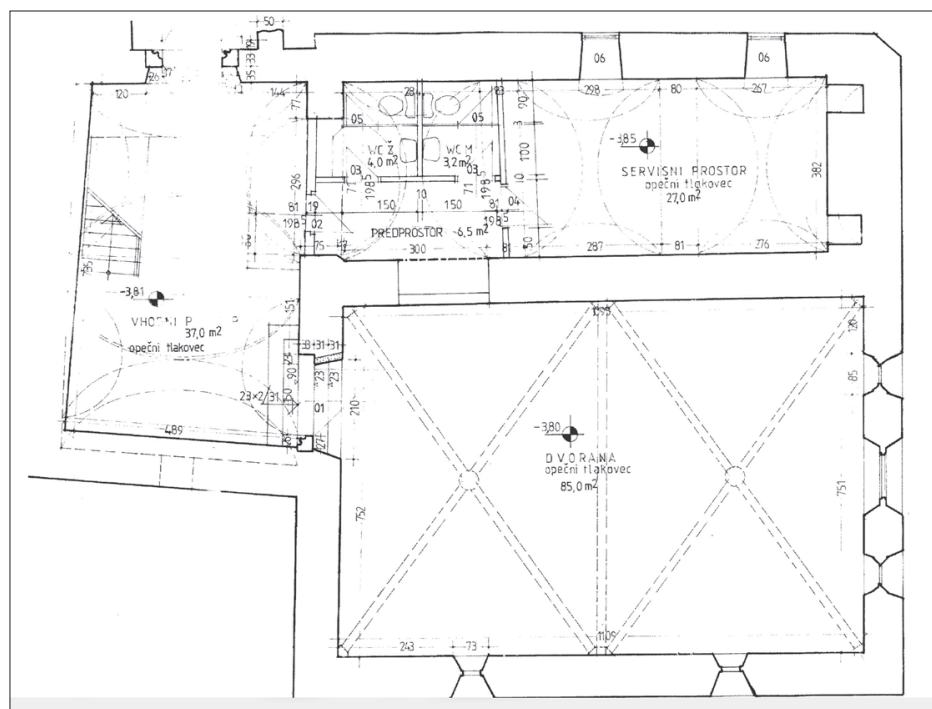

23. Maribor synagogue, reconstruction plan, after 1992 
It is also evident that some findings, even conclusions decisive for the restoration, are contradictory, even within the same publication. ${ }^{68}$ Furthermore, there is also a lack of visual material to support the argumentation and an enduring mystery as to why the previous findings, carried out before the initiation of the work, are not cited. Stele is cited by Mikuž once in Judovski zbornik, but in reference to another building. ${ }^{69}$ There is not a single mention of Curk. Could it be that the work of the previous researchers from the same institution was not included in the research?

If we try to understand and follow the sequence of decision making, the best way to begin is to work backwards and begin in 1999, when the renovation of the synagogue was completed. The principal chief conservator, Janez Mikuž, explained in his report, that "in spite of the older, appealing speculations about the age and building continuity of the Maribor synagogue, we have to focus in our case on the findings providing data on her dimensions, appearance, and architectural elements and define it as a building which was created in todays' materially-documented image, during the cultural flourishing of the Maribor Jews, in the middle of the 15th century". ${ }^{70}$

His statement related to the history of the community is not entirely accurate, as the situation in the middle of the century was actually already far from ideal..$^{71}$ Although Mikuž presented the presumed phases of the building development, it would be of enormous interest to provide at least a hint as to the "older, appealing speculations" he probably shared with his colleagues. ${ }^{72}$ What were the thoughts of the professional staff involved in the restoration about the other building stages? Some solid evidence would be more than helpful to initiate further research of the building, as would discussion of the most crucial of all the questions regarding the synagogue, although apparently not up for scrutiny: was the architectural evidence vital for the reconstruction truly as solid as claimed by Mikuž and the architect in charge of reconstruction, Irena Krajnc Horvat? ${ }^{73}$

The main, as yet unanswered, questions in relation to the complex topic of the renovation of the Maribor synagogue are the following: what were the vaults like and the main religious spacewas it a single hall or divided by columns; what were the openings (windows, doors) of the space like and where were they located; and how was the interior equipment positioned, necessary for the rituals, like the bimah, Torah arch etc. ${ }^{74}$

The most important finding for the reconstruction was the discovery of a large quantity of vault and keystones, since it was, as Mikuž stated, given the angles between the ribs of the keystones, extremely straightforward to separate those belonging to the synagogue's vault from those

68 It is not my purpose to criticise procedures in the past in this era of digitalisation when it is so much easier to obtain information. I would only like to point out the basic requirements of the doctrine-proper documentation and presentation of the findings.

69 MIKUŽ 2000 (n. 10), p. 168, n. 8 .

70 MIKUŽ 2000 (n. 10), p. 167: »Ne glede na starejše, vabljive špekulacije o gradbeni starosti in gradbeni kontinuiteti mariborske sinagoge, se moramo v našem primeru omejiti na najdbe, ki nam dajejo podatke o njeni velikosti, njeni pojavnosti ter arhitektonskih elementih in jo opredeljujejo kot objekt, ki je v danes materialno dokumentirani podobi nastal v obdobju ekonomskega in kulturnega razcveta mariborskih Judov, to je sredi 15 . stoletja."

${ }^{71}$ In the middle of the 15th century the situation of Jews in Styria deteriorated heavily due to the general financial crisis and Christian moneylending competition. See Jože MLINARIČ, Judje na slovenskem Štajerskem do njihove prisilne izselitve v letu 1496, Judovski zbornik 2000 (n. 10), p. 62. The flourishing of the Jewish community was well before 1445, when the chief rabbi Isserlein left for Wiener Neustadt. See KEIL 2006 (n. 1).

72 MIKUŽ 2000, (n. 10), p. 167.

73 See KRAJNC HORVAT, MIKUŽ 2000 (n. 10).

74 PREMK, PREMK 2015 (n. 17), p. 47. 

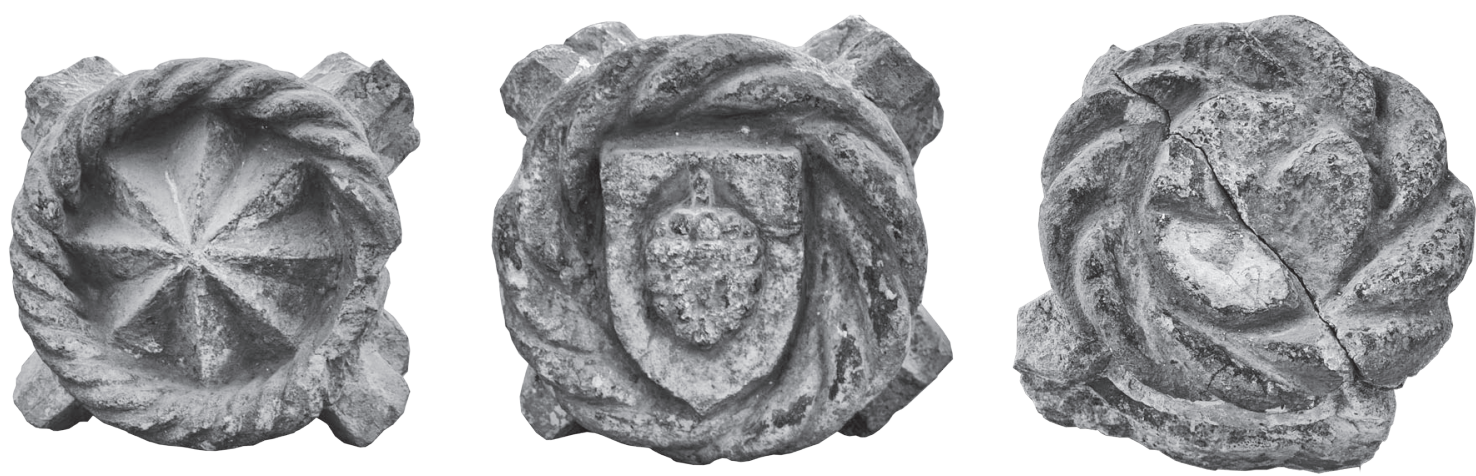

24.-26. The keystones with outset of perpendicular crossed ribs, Maribor Synagogue, Centre of Jewish Cultural Heritage

which were part of the Church of All Saints. ${ }^{75}$ It was on the basis of these keystones and crossing ribs that the vault ratio and timeframe of the building phase was established.

However, we cannot help but ask a simple question here: how many keystones did they actually find? And how many did they know of? It should not be that difficult to find out.

But we do not get an exact answer in Judovski zbornik, nor in the 1999 report on the restoration. What we do get is upsetting from the perspective of modern conservation science. ${ }^{76}$ When discussing the building state before the initiation of the works, Mikuž mentions two keystones, along with three steeped buttresses in the southern façade - the only testimony to the long history and medieval origins of the building. One of the two keystones displayed a Jewish symbol-a grape. ${ }^{77}$ In the next sentence he continues: "the ribs of the two keystones contain an outset of perpendicular crossing ribs" ${ }^{78}$ They indeed contain almost perpendicular crossing ribs, but neither of the two keystones was the one with the grape. The IPCHS photo documentation clearly shows the initial state of preservation from 1992, that those two keystones were the same as those photographed by Stele and further documented by Curk. The location of the keystone with the grape also is very well photo-documented. Even with no knowledge of this, Mikuž quotes a translated description of the synagogue by the renowned 19th century historian Rudolf Gustav Puff in the same report. ${ }^{79}$ Puff documented the grape, built into the wall of the sextons' house on the eastern side of the synagogue, above the basement entrance, accessible through the stairs from the department of the benefice. ${ }^{80}$

So suddenly there is not a single keystone ${ }^{81}$ or two, as mentioned by Mikuž, but there are three (figs. 24-26), which were very well documented in the previous literature and documentation, and

75 MIKUŽ 2000 (n. 10), p. 167: »Osnovna baza podatkov, ki nas na to navajajo, je veliko število ohranjenih reber gotskega oboka ter sklepniki, katerim je glede na kote med rebri, ki iz njih izhajajo, zelo preprosto opredeliti gradbeno fazo oziroma jih ločiti na tiste, ki so bili del oboka sinagoge, in tiste, ki so bili del oboka cerkve Vseh svetnikov."

76 The lack of professionalism, self-assertion, irrational management of resources, making compromises under pressure, political and other bias, etc. pose imminent dangers to monument preservation. See Barbara MUROVEC, Pretekle vojne in sedanji spomini, Umetnostna kronika, 44, 2014, pp. 1-2.

77 MIKUŽ 1999 (n. 10), p. 21; UIFS ZRC SAZU, France Stele’s field notes, notebook XL, fol. 33.

78 MIKUŽ 1999 (n. 10), p. 21.

79 MIKUŽ 1999 (n. 10), p. 27.

80 PUFF 1847 (n. 64).

81 MIKUŽ 2000 (n. 10), p. 163. 


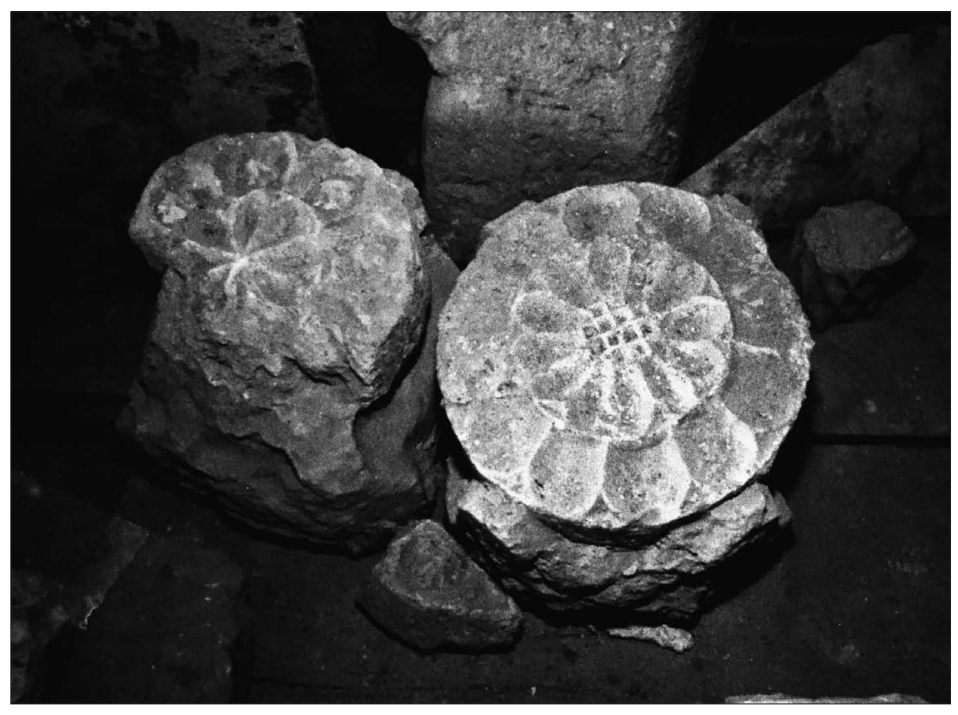

27. Two keystones with the outset of sharp-angle crossed ribs, Maribor Synagogue, Center of Jewish Cultural Heritage (the wherabouts of the right keystone unknown)

evidently related to each other. When quoting Puff that the keystone with the grape decoration belonged to a wine confraternity, ${ }^{82}$ Mikuž dated it to one of the unknown periods in the old history of the building. Should the keystones with the perpendicular crossing ribs (only two are mentioned, although there were actually three keystones found by the IPCHS which are displayed today in the synagogue) be dated to different periods? Obviously yes, in his opinion, since in a subtitle to the picture of the keystone with a "windmill", the "windmill" keystone is dated to the middle of the 15th century, that is, in the period of the reconstruction phase of the building! ${ }^{83}$

Establishing the angle of the ribs is not enough-the keystones should be measured and scanned according to contemporary methods, although nothing but confirmation of the similarity of the three keystones and their origin in the same vault is expected. ${ }^{84}$ This is further proof that the "speculations" of Stele about a three-bay division of the space and Curk's assumptions were far from trumped-up. So, finally, the (hopefully) correct number of keystones found during the restoration works is five. Three were found built-in in the façade, and two others were found separately, built-in in the interior northern part of the building (labelled B in the report, fig. 27). Mikuž uses the plural form in Slovenian (sklepniki), not the dual, as he should have, because the same two keystones were then used for the reconstruction of the main synagogue space (labelled A in the report). ${ }^{85}$ The finding of the two keystones with obviously different ornamentation and much steeper rib angle is highly significant, since they were not documented in the previous literature. According to Mikuž, they formed part of the same synagogue vault. On the basis of the crossing ribs springing up from the keystones, the width to length bay ratio would be 1:1.3, partitioning the main synagogue space into two rib-vaulted bays. Mikuž analysed the form of the ribs, dating the

82 In fact, a grape is a common symbol and the Jewish wine trade is well documented in historic documents. See MLINARIČ 2000 (n. 10), p. 70.

83 MIKUŽ 2000 (n. 10), p. 163. But, why then, did the windmill keystone not serve at least as the basis for the reconstruction? Was it because the outset angle of the ribs did not confirm a two-bay theory of the inner space?

84 The potential difference in the angle of the ribs, which might have led Mikuž to date them into different periods, is very easily explained by the different bay dimensions, See PREMK, PREMK 2015 (n. 17), p. 55. The location of the bimah was not always in the center of the interior, but was always adapted to spatial demands. If our two-column theory proves correct through $3 \mathrm{D}$-CAD scanning, the bimah was located somewhere between the two columns.

85 MIKUŽ 1999 (n. 10), p. 30. 


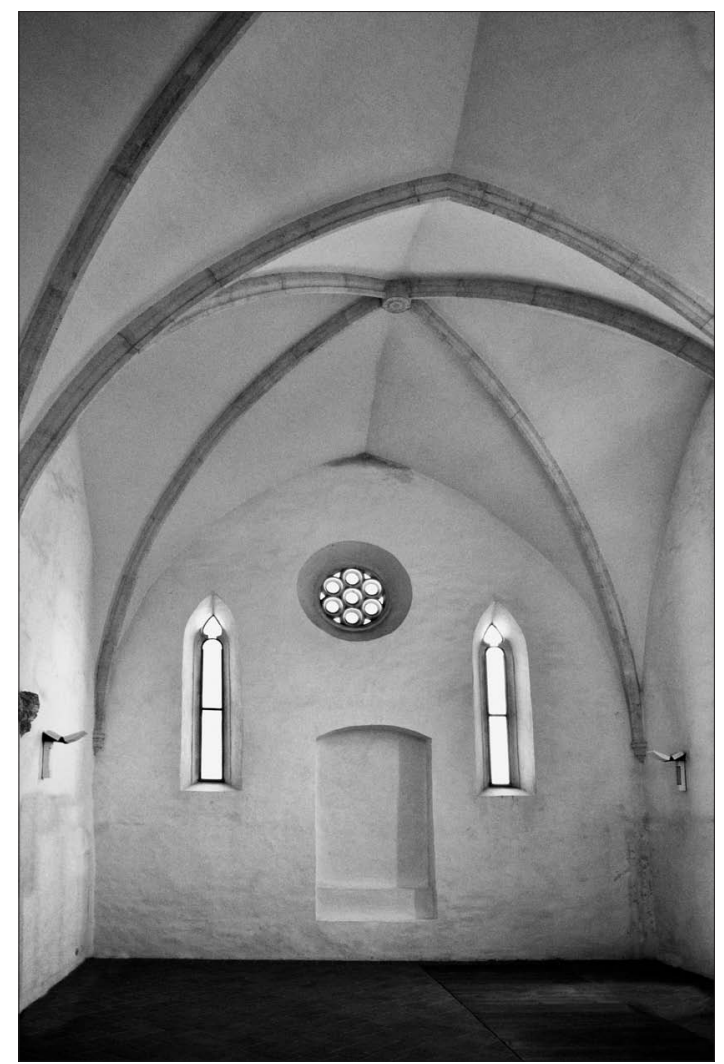

28. Maribor synagogue, the vaults and the eastern wall of the central premise two keystones to around $1500 .{ }^{86}$ The two keystones with ribs crossing at a sharp angle, as he claimed, originate from a newer stage, when the synagogue was transformed into the Church of All Saints. ${ }^{87}$

If they belong to the latter, Christian phase of building, why were they then used in the reconstruction? Why did they not instead use the abundant building evidence, ${ }^{88}$ dated by the project leaders to the middle of the century, such as the keystone with the ribs crossing at a perpendicular angle? ${ }^{89}$

Does the reconstructed space, one of the most renowned medieval synagogue buildings in Europe today, reflect building continuity from the middle ages to the present; does it in fact indicate a Christian phase (fig. 28)? Or is it a partial reinvention?

As is more than evident from the disclosed facts, the entire preservation project carried out in the 1990s should be thoroughly reanalysed. In the most systematic presentation of the synagogue's building history until today, Anja Premk and I have already established its complexity and come to quite different conclusions from those put forward by the IPCHS. ${ }^{90}$

We have to disagree with the statement of the principal investigator about the archaeological research carried out inside the synagogue, in spite of its' thoroughness, as not providing enough concrete evidence about the possible older synagogue stages (fig. 29). ${ }^{91}$ We do agree, though, that

86 MIKUŽ 2000 (n. 10), p. 163.

87 MIKUŽ 2000 (n. 10), pp. 168-169.

88 MIKUŽ 2000 (n. 10), p. 169.

89 There is no archival or other evidence that the interior vault was modified after the synagogue was changed into the church apart from the fact that the name of the new owner was carved on the lintel of the window on the northern wall. There usually is a very good reason for profound changes in building structures. After a thorough examination of the sources we established that there were most probably four medieval building phases: the earliest (late 13th or early 14th century), the second before 1354, the third, late gothic phase (1465-1477) and the Christian phase (1497-1501), with almost no architectural modifications of the interior. See PREMK, PREMK 2015 (n. 17), p. 57. The suggested rectangular, south oriented Romanesque shape of the first stage, followed by a 6 bay space division, with the vault supported by two pillars and oriented towards the east as well as the later modifications, still need to be confirmed by the 3D CAD scanning. But the suggested solutions have a solid base in the archeological findings.

90 PREMK, PREMK 2015 (n. 17).

91 MIKUŽ 2000 (n. 10), p. 166. The archeological work, though lacking the methodology of contemporary medieval archeology practices, was carried out with outmost care by Ivan Tušek and Mihela Kajzer and is well documented. For the archeological report see MIKUŽ 1994 (n. 10). For a more detailed examination of the archeological findings, see PREMK, PREMK 2015 (n. 17), pp. 40-46. 


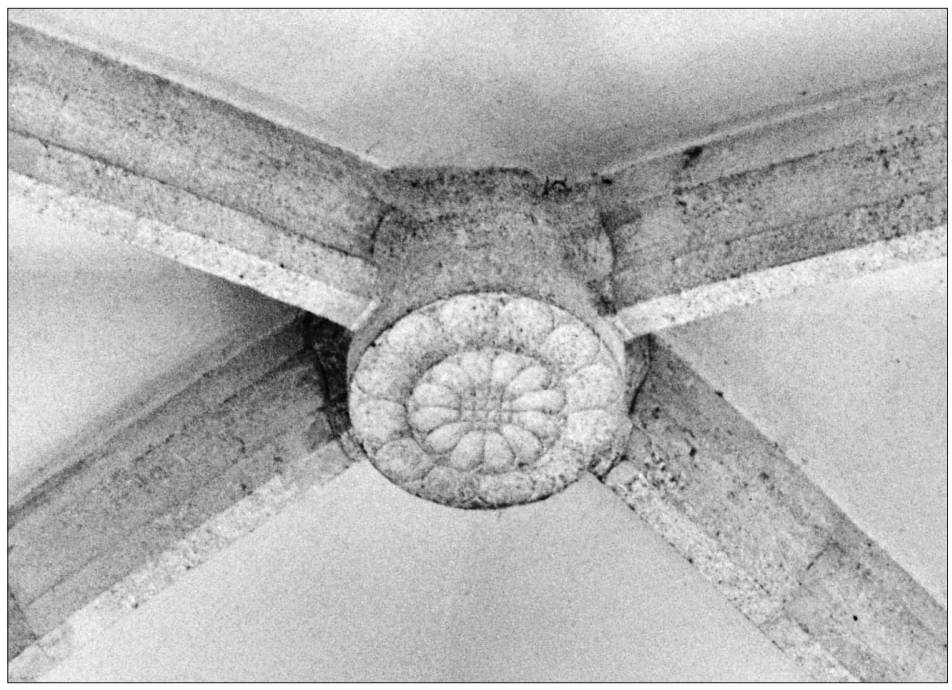

29. Maribor synagogue, reconstructed copy of one of the two keystones with the outset of sharp-angle crossed ribs

the evidence used by the IPCHS for decision-making and finally reconstructing the specified building phase is anything but convincing. ${ }^{92}$ If the profiled consoles found during the restoration work indicated a three-bay division of the space, ${ }^{93}$ why should it be then reconstructed into two bays? The argument was that only a two-bay division matched the buttresses on the outside wall. But what about the other building phases? What if the buttresses were lower at the time, and perhaps extended much later because of the static demands of the new construction? The only "solid" evidence of the two consoles supporting the ribs in the middle of the two alleged bays was a "remains of a console or better, an opening for a console" on the northern wall. ${ }^{94}$ An opening in the wall can also be used as a support for a wooden beam or for many other purposes, even a result of later modifications of the space. Was it really an opening for a console? Why did they not find a similar opening or a console on the other side? Eventually, in order for the reconstruction of the two-bay vault system to be made possible, the angle of the roof had to be lifted. What if the two keystones used in the reconstruction of the main synagogue space (A), actually belonged to the two bay vault of the space on the western side (B)? 3D-CAD projection would provide the answer.

It is always difficult to question past procedures, even in search of the truth. The dilemmas presented here are only the tip of the iceberg of the set of issues linked to the former synagogue and its building history. Yet, even with all the mistakes and misconceptions of the renovation, the building still serves as an exceptional testimony to the past. Only after all the architectural elements are located and processed accordingly can the archaeological work be concluded on the eastern side and the location of the former Jewish cemetery ascertained. It will then be possible to publish a comprehensive study revealing a truthful or at least a close-to-the truth account of the synagogue building and its various phases. It is our responsibility and obligation..$^{95}$

92 We are not going to comment on the architectural part of the project, but we do wonder, why did they use two identical keystones in the new vault, making duplicates of a single keystone, instead of simply copying the two preserved keystones?

93 MIKUŽ 1999 (n. 10), p. 23.

94 MIKUŽ 1999 (n. 10), p. 26: »Pri podrobnejši preiskavi smo našli ostanke ali bolje pozicijo pete konzole, ki je bila postavljena centralno«.

95 The research for this article was conducted in the scope of the Slovenian-Israeli bilateral project Digitization of Jewish Heritage of Slovenia (NI-0003), which is co-funded by the Slovenian Research Agency from the state budget. 


\section{Mariborska sinagoga pod drobnogledom}

\section{Povzetek}

$\mathrm{V}$ zadnjih dveh desetletjih je prišlo v raziskavah srednjeveške in novodobne sinagogalne arhitekture v Evropi do velikega napredka. Ko so se na mariborski območni enoti Zavoda za varstvo kulturne dediščine Slovenije (ZVKDS) na začetku devetdesetih let prejšnjega stoletja lotili celovite prenove nekdanje sinagoge v Mariboru, so bile raziskave judovske nepremične dediščine srednjega veka šele $\mathrm{v}$ povojih. Temelje prihodnjim raziskavam je sicer postavil Richard Krautheimer že pred drugo svetovno vojno s sistematičnim raziskovanjem stilnih in tipoloških značilnosti v tistem času bolj prepoznavnih srednjeveških sinagog, ki jih je v prvi četrtini 20. stoletja dokumentiralo Društvo za raziskovanje judovske umetnostne dediščine (Gesellschaft zur Erforschung jüdischer Kunstdenkmäler) v Frankfurtu na Majni. V osemdesetih letih je izšel pregled evropske arhitekture sinagog Carol Herselle Krinsky, ki je vključeval tudi nekaj sinagog s področja Avstrije in Balkana. Vendar mariborska sinagoga, takrat praktično neznana v širšem srednjeevropskem okviru, v njih ni bila omenjena. Znana je postala šele leta 1998 z objavo poročila Ruth Ellen Gruber in Samuela Gruberja iz Komisije za zaščito ameriške dediščine v tujini (Commission for the Preservation of America’s Heritage Abroad) ter z objavami poročil o obnovi, ki so jih izdali na mariborski območni enoti Zavoda za varstvo kulturne dediščine.

Skoraj dve desetletji po končani prenovi spomenika leta 1999 je slika popolnoma obrnjena. Prenovljena sinagoga velja za enega glavnih dosežkov prenove starega mestnega jedra Maribora, ki se je začela v osemdesetih letih. Zaradi njene izjemne zgodovinske in arhitekturne vrednosti je ne le ena najbolj prepoznavnih turističnih atrakcij mesta, temveč ima visok mednarodni ugled tudi v znanstvenih krogih. Stavba, kot se kaže po prenovi, je postala eden pomembnejših primerov srednjeveške aškenaške tipologije sinagog, kot se je razvil predvsem na avstrijskem področju. V posebnem poglavju svoje monografije, izdane leta 2007, jo je vključil v razvid aškenaških srednjeveških sinagog tudi Simon Paulus. Razlog za to ne tiči le v njeni relativni velikosti in zgodovinskem pomenu mariborske judovske skupnosti, temveč predvsem $v$ tem, da je stavba kljub posegom v stavbno tkivo in spremembam namembnosti skozi stoletja ohranila svojo sporočilnost in zgodovinsko identiteto. Prenova, ki je »lep primer obnove kulturnega in zgodovinskega spomenika v starem mestnem jedru«, kot je nedavno zapisal nekdanji direktor Judovskega kulturnega centra Sinagoga Maribor Marjan Toš, in eden večjih konservatorskih posegov na Slovenskem v prvem desetletju po osamosvojitvi, je vseeno pustila nekaj pomembnih odprtih vprašanj. Ta vprašanja se večinoma dotikajo med prenovo ugotovljenih, a ne natančneje definiranih starejših stavbnih faz in nedokončanih arheoloških raziskav predvsem pred vzhodno stranico današnjega objekta. Ob vpogledu v obsežno dokumentacijo prenove, hranjeno na mariborski območni enoti ZVKDS in ob podrobnejši seznanitvi s stavbno problematiko in dozdajšnjo literaturo se je pokazalo, da je tematika, vezana na stavbno zgodovino, veliko kompleksnejša, kot je bilo to razvidno na podlagi odločitve o prenovi najbolj dokumentirane judovske stavbne faze objekta. Ob vprašljivi argumentaciji v končnem poročilu prenove in strokovnem članku, ki ga je v Časopisu za zgodovino in narodopisje objavil odgovorni konservator Janez Mikuž, in po pregledu gradiva se porajajo upravičeni dvomi tudi o uspešnosti same prenove.

Za odgovore na odprta vprašanja bo tako treba počakati ne le na dokončanje arheoloških izkopavanj, temveč bo potrebna temeljita evalvacija virov in do zdaj opravljenih raziskav s strani ZVKDS, lociranje stavbnih elementov, najdenih med zadnjo prenovo in vsemi drugimi spomeniškovarstvenimi posegi v prejšnjem stoletju, in končno 3D skeniranje in izdelava 3D-CAD modelov, ki bosta omogočila virtualno rekonstrukcijo posameznih srednjeveških stavbnih faz. To ob hitrem razvoju digitalne tehnologije $\mathrm{v}$ zadnjem času in predvsem ob številnih primerih rekonstrukcij srednjeveških in novoveških sinagog $\mathrm{v}$ 
Evropi ne bi smel biti večji problem. Konkretni primeri tovrstnih rekonstrukcij so virtualni posnetki nekdanjih sinagog v Avstriji, ki so jih naredili študenti Tehnične fakultete v Gradcu in na Dunaju. Sandra Glatz si je pri virtualni rekonstrukcij sinagog v Oberwaltersdorfu in Ebenfurthu pomagala tudi z analogijami, pri čemer je kot vzorčni primer služila tudi mariborska sinagoga s svojimi ohranjenimi ali rekonstruiranimi stavbnimi elementi.

Članek ni namenjen reševanju odprtih vprašanj, temveč predvsem retrospekciji opravljene spomeniškovarstvene dokumentacije, raziskav in posegov v 20. stoletju v luči nedavnega napredka v raziskavah arhitekturne zgodovine in tipologije sinagog $\mathrm{v}$ aškenaškem prostoru.

Mariborska sinagoga, katere stavbno zgodovino lahko v grobem razdelimo na srednjeveško judovsko fazo (do 1497), krščansko fazo (do 1784) ter obdobje posvetne uporabe poslopja (od 1785 dalje), nikoli ni povsem izgubila svojega genius loci. Kljub predelavam je bila njena identiteta znana in s posebno zavzetostjo se je dokumentacije in prvih konservatorskih del na objektu lotil tudi France Stele leta 1926. Njegova dokumentacija in korespondenca v zvezi s prvimi posegi na objektu sta še posebej pomembni, saj je iz njiju in narejenega arhitekturnega posnetka razvidno stanje objekta in najdenih arhitekturnih členov pred drugo svetovno vojno. Poleg Steleta je na pomen mariborske sinagoge od šestdesetih let 20. stoletja dalje opozarjal tudi Jože Curk, ki mu je spomenik leta 1964 uspelo tudi uvrstiti v register kulturno-umetnostnih spomenikov. V podrobnejšem opisu in ovrednotenju spomenika leta 1989, ki ga je uvrstil celo v razvid dvanajstih najpomembnejših gradbenih objektov v Mariboru, je potrdil Steletovo najdbo treh sklepnikov, delno vzidanih $\mathrm{v}$ fasado, nakazal pa je tudi na možen kvadratast, proti jugu obrnjen tloris starejše faze objekta.

Pred celovito prenovo, ki se je začela 1992, je bilo ugotovljeno, da je treba ohraniti vse urbanistične značilnosti tega območja, kot so poleg nekdanje sinagoge sočasni stavbi fond, domnevni prostor judovskega pokopališča in ploščad severno od sinagoge, ter judovsko obredno kopališče. Ker opravljene temeljite arheološke raziskave po mnenju odgovornega konservatorja Janeza Mikuža niso prinesle oprijemljivih podatkov o starejših gradbenih fazah, so bili pri odločitvi za način prenove merodajnejši ohranjeni arhitekturni členi različnih stavbnih faz. Odločili so se za stavbno fazo iz srede 15. stoletja, ko naj bi judovska skupnost doživela največji razcvet; o njej priča največ ohranjenih arhitekturnih najdb. Kot bistveni so se za način prenove izkazali ohranjeni sklepniki in koti med nastavki reber, ki iz njih izvirajo. Mikuž ne navede točnega števila najdenih sklepnikov, saj od treh sklepnikov, najdenih na fasadi, omenja le dva in še to v primeru sklepnika z motivom grozda z napačno lokacijo zatečenega stanja. Sklepnik z grozdom po njegovem mnenju izvira iz neke starejše gradbene faze, čeprav je stilno povsem soroden obema drugima sklepnikoma, ki sta jih pred njim dokumentirala že Stele in Curk. Nastavki reber se v vseh treh primerih sekajo bolj ali manj pod pravim kotom, enega izmed njih pa Mikuž datira v sredo 15. stoletja, torej v čas rekonstrukcije sinagoge. Vprašanje, ki se pri tem zastavlja, je, zakaj so potlej vzeli kot model za rekonstrukcijo stanja v sredi 15. stoletja enega od dveh sklepnikov, ki so jih našli v kletnem prostoru med prenovo stavbe in katerih rebra se sekajo pod ostrim kotom. Torej (le) enega od dveh sklepnikov, ki ju je Mikuž datiral v krščansko fazo stavbe ok. 1500. Ali je bila torej rekonstruirana cerkvena faza objekta? Ali pa gre za (delno) reinvencijo prostora? Vsekakor strokovna argumentacija ni prepričljiva - oba sklepnika pa bi ravno tako lahko pripadala oboku predprostora na zahodni strani. Primer (skupaj petih) najdenih sklepnikov je le vrh kopice odprtih vprašanj, ki se porajajo $\mathrm{v}$ zvezi z nekdanjo sinagogo in njeno prenovo. Kompleksna tematika je bila že podrobneje predstavljena v knjižici o mariborski sinagogi (PREMK, PREMK 2015), nakazane pa so bile tudi rešitve, ki se zdijo ob upoštevanju dosedanjih arheoloških najdb najverjetnejše. Iz arheoloških raziskav je možno ugotoviti starejše stavbne faze, 3D-CAD skeniranje ohranjenih stavbnih členov in virtualna rekonstrukcija prostora pa bosta šele dokončno potrdila izgled posameznih stavbnih faz. 
Oelgari na to Rimol

\section{Proicluta pur}

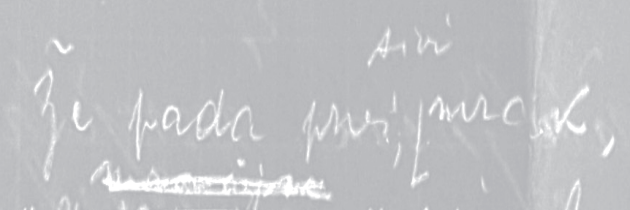

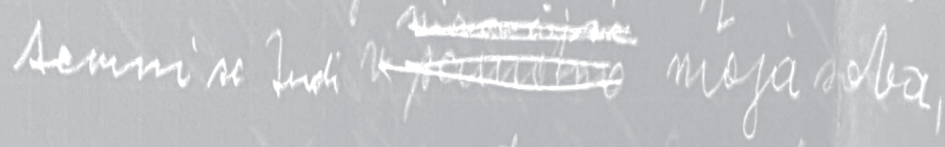

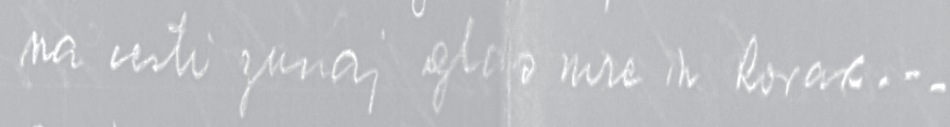

in ion sem karkat tredi groba.

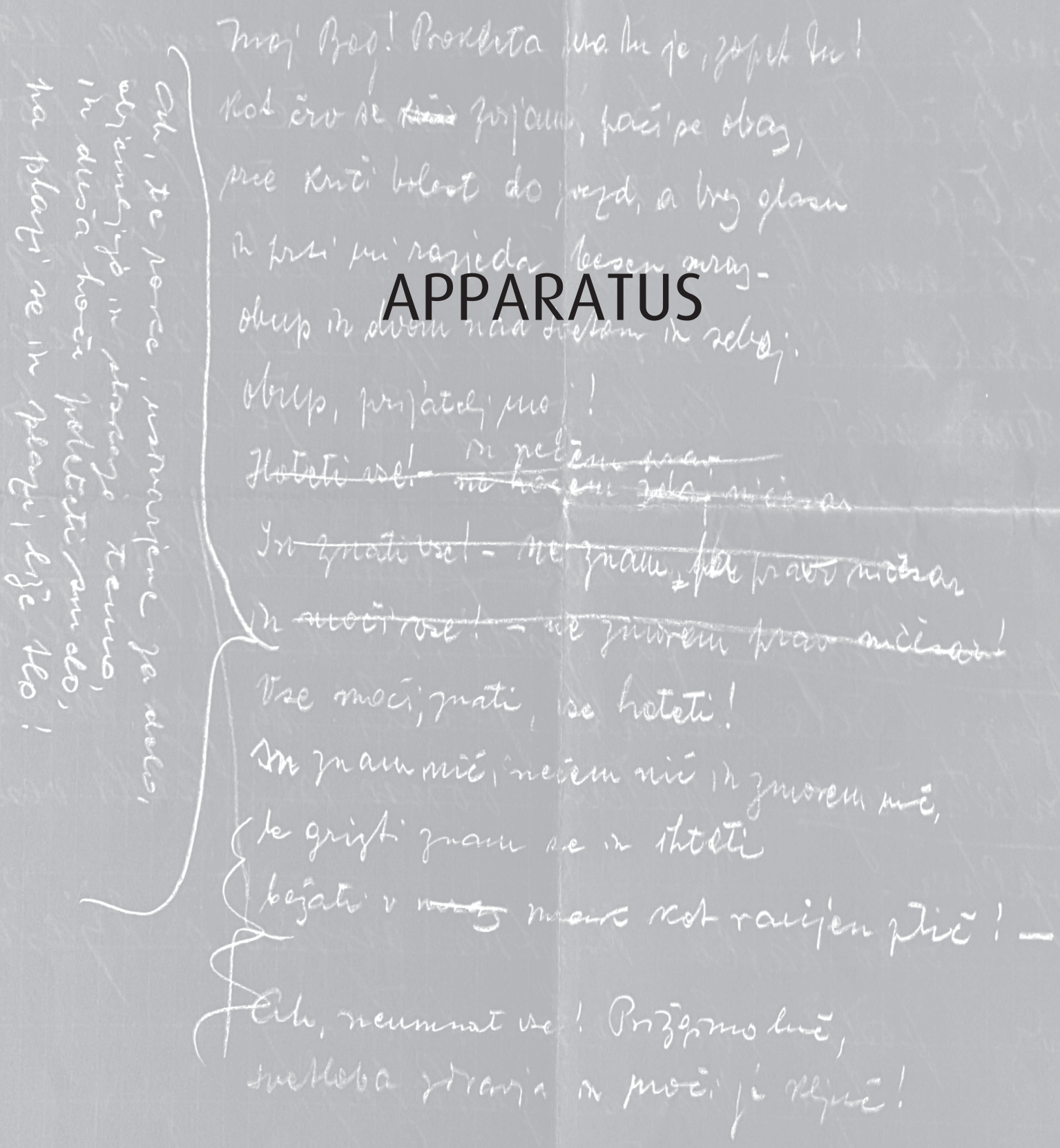

Sha ha ha ba: Ma muxi' mn' by: 



\section{IZVLEČKI IN KLJUČNE BESEDE}

\section{ABSTRACTS AND KEYWORDS}

\section{Jasmina Čubrilo}

Jugoslovansko: toponim ali ideologija v umetnostnozgodovinski sistematizaciji umetnosti 20. stoletja $v$ besedilih Miodraga B. Protića

\subsection{Izvirni znanstveni članek}

Prispevek analizira ideološki kontekst in zgodovinske okoliščine, v katerih je Miodrag B. Protić snoval in realiziral umetnostnozgodovinsko sistematizacijo pred- in povojne jugoslovanske umetnosti. Avtorica problematizira koncept »jugoslovansko « v sintagmi »jugoslovanska moderna umetnost « in ga interpretira kot večpomenko. Prispevek obravnava učinke različnih diskurzov o »jugoslavizmih« na Protićevo razumevanje koncepta.

Ključne besede: Miodrag B. Protič, jugoslovanska umetnost, moderna umetnost, sistematizacija umetnosti, Muzej sodobne umetnosti Beograd

\author{
Vesna Krmelj \\ France Stele v luči mladostne korespondence z Izidorjem \\ Cankarjem
}

\subsection{Izvirni znanstveni članek}

Prispevek obravnava korespondenco med dvema ključnima predstavnikoma dunajske umetnostnozgodovinske šole v slovenskem prostoru - Francetom Steletom in Izidorjem Cankarjem. Razprava sledi njunemu dopisovanju od začetka študija do konca leta 1913 in se osredotoča na Steletovo uredniško in javno delovanje v obdobju pred prvo svetovno vojno.

France Stele je kmalu po vpisu na Dunajsko univerzo prevzel uredništvo Zore, glasila katoliškega akademske-

\section{Jasmina Čubrilo}

Yugoslav: Toponym or Ideology in Miodrag B. Protićs

Art-Historical Systematization of 20th-Century Art

\subsection{Original scientific article}

The article analyzes the ideological context and historical circumstances in which Miodrag B. Protić initiated and realized the art-historical systematization of 20thcentury art from the territory of pre- and postwar Yugoslavia. The concept of "Yugoslav" in the syntagm "Yugoslav modern art" is problematized, interpreted here as a polysemy whose meanings were produced by various discourses about Yugoslavism; the effects of those found in Protić's articulations are mapped and examined.

Keywords: Miodrag B. Protić, Yugoslav art, modern art, art criticism, art systematization, Museum of Conteporary Art in Belgrade

\section{Vesna Krmelj}

An Insight into France Stele through his Early Adulthood Correspondence with Izidor Cankar

\subsection{Original scientific article}

The article deals with the correspondence between two key representatives of the Vienna School of Art History at the University of Ljubljana, France Stele and Izidor Cankar. The discussion follows their correspondence from the start of their studies until the end of 1913, and focuses on Stele's editorial and public activities in the pre-WW1 period. Soon after enrolling at the University of Vienna, France Stele became the editor of Zora, a bulletin of the Catholic Academic Society Danica and invited Cankar, who was 
ga društva, in k sodelovanju povabil Cankarja, ki je tedaj študiral v Louvainu. Stele in Cankar sta se spopadla s predsodki ob sprejemanju moderne umetnosti med slovenskimi katoliškimi izobraženci zlasti v primeru sodobne cerkvene arhitekture.

Steletov esej Apologija moderne umetnosti, objavljen leta 1911, lahko razumemo kot prvi neposredni naslon na dunajsko šolo umetnostne zgodovine. Vsebina članka in odzivi nanj sicer niso neposredno odmevali v ohranjeni korespondenci med Steletom in Cankarjem, vendar pa je sam način, kako sta se kolega kasneje dopolnjevala in podpirala, zelo značilen za njuno vodenje javne polemike.

Ključne besede: France Stele (1886-1972), Izidor Cankar (1886-1958), korespondenca, zgodovina umetnostne zgodovine, Dunajska umetnostnozgodovinska šola, slovenska umetnostna zgodovina, študentska društva, slovenski katoliški izobraženci, slovenski študenti na Dunaju

\section{Barbara Murovec \\ Historizirana podoba naročnika. Attemsova družinska portreta in Rembov avtoportret iz brežiškega gradu}

\subsection{Izvirni znanstveni članek}

V prispevku sta analizirana družinska portreta Ignaca Marije grofa Attemsa (Ljubljana, 15. avgust 1652 - Graz, 13. december 1732) s sinovi in Marije Regine grofice Wurmbrand, poročene Attems (Graz, 3. junij 1659 - Brežice, 24. april 1715) s hčerko in sinovoma, ki sta bila $\mathrm{v}$ oljni tehniki naslikana za veliko dvorano gradu Brežice (nem. Rann). Od leta 2010 sta hranjena v Dvorcu Eggenberg Deželnega muzeja Joanneum. Naslikal ju je Frančišek Karel Remb (Radovljica, 14. oktober 1674 - Dunaj, 23. september 1718), ki je sebe upodobil v celopostavni figuri $\mathrm{v}$ fresko tehniki na reprezentativnem mestu sredi dvorane, in sicer kot edino osebo iz sedanjosti. Ignac Marija, ki se je arhivsko izpričano udejstvoval kot arhitekt pri gradnji in prezidavah svojih bivališč, je na portretu predstavljen kot arhitekt-ustvarjalec in kot arhitekt-začetnik nove štajerske družine. Pretehtana inscenacija historiziranih portretov, s katerima sta želela ponosna starša za večnost ohraniti podobo umetnostno darežljive in ambiciozne družine, ki prosperira v miru in ljubezni, se nam v povezavi s slikarjevim avtoportretom kaže kot izjemna. Čeprav lahko pokažemo na številne mogoče vzore, so ti slikarju in naročniku služili le kot inspiracija za edinstveno umetniško celoto.

Ključne besede: Štajerska, Frančišek Karel Remb, Ignac Marija grof Attems, Marija Regina grofica Wurmbrand, družinski portret, avtoportret, naročnik-arhitekt, 1700, baročno slikarstvo studying in Louvain, to participate. After 1911, when both studied in Vienna, Stele and Cankar directly addressed prejudice on the acceptance of modern art among Slovene Catholic scholars, especially in cases of contemporary church architecture. Stele's essay "The Apology of Modern Art", published in 1911, can be understood as his first direct application of the principles of the Vienna School of Art History. The content and critical responses to the article were not directly recorded in the preserved correspondence between Stele and Cankar; however, the way in which the two colleagues later complemented and supported one another is highly characteristic of how they also led public discourse.

Keywords: France Stele (1886-1972), Izidor Cankar (1886-1958), correspondence, history of art history, the Vienna School of Art History, Slovenian art history, student associations, Slovene Catholic scholars, Slovenian students in Vienna

\section{Barbara Murovec \\ The Patron's Historized Image. Attems' Family Portraits and Remp's Self-Portrait in the Brežice (Rann) Castle}

\subsection{Original scientific article}

The paper analyzes the family portraits of Ignaz Maria, Count of Attems (Ljubljana/Ger. Laibach, 15 August 1652Graz, 13 December 1732), with his sons, and Maria Regina, Countess of Wurmbrand with her daughter and sons, painted in oil technique for the Great Hall in the Brežice Castle (Ger. Rann). The portraits have been kept at Schloss Eggenberg of the Landesmuseum Joanneum since 2010. They were painted by Franz Carl Remp (Radovljica/Ger. Radmannsdorf, 14 October 1674-Vienna, 23 September 1718), who depicted himself in fresco technique in full figure in a representative place in the center of the hall as the only person from the present. In the portrait, Ignaz Maria, who, according to archival sources, participated as an architect in the construction and rebuilding of his residences, is presented as an architect-creator and an architect-founder of the new Styrian family. A careful arrangement of historized portraits, with which the proud parents wanted to preserve for eternity the image of an artistically generous and ambitious family that prospers in peace and love, in connection to the painter's self-portrait, is exceptional. Even though numerous possible sources for the paintings can be named, they served only as an inspiration for a unique work of art.

Keywords: Styria, Franz Carl Remp, Ignaz Maria, Count of Attems, Maria Regina, Countess of Wurmbrand, family portrait, self-portrait, patron-architect, 1700, Baroque painting 


\section{Mija Oter Gorenčič}

Pro remedio et pro salute animae nostrae.

Memoria v srednjeveškem umetnostnem okrasju cisterce

$v$ Stični kot odsev tesne povezanosti s plemstvom

\subsection{Izvirni znanstveni članek}

Članek prinaša sistematičen pregled nad listinskimi omembami pokopov laikov v cistercijanskem samostanu Stična in njihovim vplivom na umetnostno zasnovo cisterce. Najstarejši dokaz povezav s plemstvom je krog z grbovnim ščitkom tik nad nekdanjim nišnim grobom v severovzhodnem kotu križnega hodnika ob prvotnem meniškem vhodu v cerkev. Naslikan je bil pred obokanjem križnega hodnika, ki se postavlja $\mathrm{v}$ čas okrog leta 1228. Do tega leta arhivski viri med pokopanimi v samostanu omenjajo le soustanovitelje samostana, Višnjegorske grofe in njihovo rodbino. Po sredini 13. stoletja so v skladu s prakso v drugih cistercijanskih samostanih pokopi laikov postali pogostejši. Najstarejša listina, ki se najverjetneje nanaša na pokop laika v cerkvi, sega v leto 1293. Avtorica v članku argumentirano podaja številne nove interpretacije in razpravlja o identifikaciji grbov, mestu, kjer so bili pokopani soustanovitelji samostana, identifikaciji oseb, ki so bile pokopane v pokopališki kapeli, in nišnem grobu pod najstarejšim grbom v križnem hodniku.

Ključne besede: cistercijanski samostan Stična, plemstvo, srednji vek, pokopi, križni hodnik, grbi, nagrobniki, nišni grob, turjaška kapela, Auerspergi, Višnjegorski, Čreteški, Svibenski

\section{Friedrich Polleroß}

Brezmadežna, cesar Leopold I. in rimski tezni list ljubljanskih frančiškanov

\subsection{Izvirni znanstveni članek}

Članek obravnava tezni list Jana Onghersa iz leta 1700, ki je bil doslej neznan oz. smo poznali le pripravljalno risbo zanj, hranjeno v Budimpešti. Grafika vključuje naslednje ikonografske teme: habsburško češčenje Brezmadežne, zmagoslavje nad Otomani, rivalstvo med frančiškanskim ter jezuite in njihove tezne liste. Obenem osvetljuje politično-umetnostne zveze med Dunajem, Ljubljano, Augsburgom in Prago.

Ključne besede: Pietas Austriaca, Brezmadežna, Habsburžani, tezni listi, frančiškani, dominikanci, jezuiti, Joannes Duns Scotus, Otomani, Jan Onghers, Elias Nessenthaler

\author{
Mija Oter Gorenčič \\ Pro remedio et pro salute animae nostrae. \\ Memoria in Medieval Architectural Decoration of the \\ Stična Cistercian Monastery as a Reflection of its Close \\ Connection with the Nobility
}

\subsection{Original scientific article}

The paper offers a systematic overview of the documented burials of laymen in the Cistercian monastery in Stična and of their influence on the artistic design of the monastery. The oldest proof of its connection to nobility is a circle with a coat-of-arms above the former tomb niche in the northeastern corner of the cloister, next to the original monastic entrance to the church. It was painted before the vaulting of the cloister, which is dated around 1228. According to archival sources, until that year, only the co-founders of the monastery, the Counts of Weichselberg, and their families were buried in the monastery. After the middle of the 13th century, the burials of laymen became more frequent, in accordance with the practice in other Cistercian monasteries. Probably the oldest document referring to the burial of a layman in the church dates back to 1293 . The authoress of the paper argues several new interpretations and discusses identifications of the coat of arms, the monastery co-founders' locations of burial, the identification of persons, who were buried in the burial chapel, and the tomb niche under the oldest coat-of-arms placed in the cloister.

Keywords: Cistercian monastery Stična, nobility, Middle Ages, burials, cloister, coats-of-arms, tombstones, arcosolium, Auersperg chapel, Lords of Auersperg, Counts of Weichselberg, Lords of Reitenburg, Lords of Scharffenberg

\section{Friedrich Polleroß}

The Immaculata, Emperor Leopold I, and a Roman

Thesis Print by the Franciscans from Ljubljana

\subsection{Original scientific article}

The paper presents a Roman thesis print by Jan Onghers from 1700 that had been unknown until now; we only knew its preparatory drawing in Budapest. The graphic combines different themes: the veneration of the Immaculata by the House of Habsburg, the triumph over the Ottomans, the rivalry between the Franciscans, and Jesuits and their influence on the development of thesis prints. Moreover, it discusses the political and artistic relations among Vienna, Ljubljana, Rome, Augsburg and Prague.

Keywords: Pietas Austriaca, Immaculata, Habsburg, Thesis Print, Franciscans, Dominicans, Jesuits, Joannes Duns Scotus, Ottomans, Jan Onghers, Elias Nessenthaler 


\author{
Damjan Prelovšek \\ Plečnikov prizidek $k$ bratovi hiši $v$ Trnovem
}

1.01 Izvirni znanstveni članek

Vpogled v doslej neprebrano arhitektovo pisemsko zapuščino in nekatere druge zgodovinske vire temeljito spreminja vedenje o nastanku in opremi Plečnikovega domovanja v Trnovem. Glavni namen gradnje valjastega prizidka (1923-1924), ustvariti skupen dom za brate in sestro, se ni posrečil zaradi njihovih različnih življenjskih usod. Sprva so se vsi navduševali za hišo na sedanjem Ciril-Metodovem trgu 10, v kateri je stanovala sestra, a se je Andrej Plečnik po vrnitvi iz Idrije raje odločil za nakup hiše za trnovsko cerkvijo v Ljubljani. Popraviti je treba tudi trditev, da naj bi se Jože sprl z najmlajšim Janezom, nakar naj bi ta zapustil hišo v Trnovem. V resnici oba v njej nikoli nista skupaj stanovala. Tudi starejši Andrej svoje posesti ni dolgo užival, ker ga je disciplinska komisija spodila iz ljubljanske realke, na kateri je poučeval verouk. Odšel je za kateheta v Kočevje in se ni nikoli več za stalno vrnil v Ljubljano. Na koncu je arhitekt $\mathrm{v}$ hiši ostal sam in si jo po svoje opremil.

Ključne besede: arhitektura 20. stoletja, Jože Plečnik, Andrej Plečnik, Janez Plečnik, Marija Matkovič, adaptacija Gabrovkine hiše, hiša v Trnovem, načrt prizidka, oprema prizidka, utopija o skupnem domu.

\section{Janez Premk \\ Mariborska sinagoga pod drobnogledom}

\subsection{Pregledni znanstveni članek}

Mariborska sinagoga spada med najpomembnejše ohranjene srednjeveške sinagoge v Srednji Evropi. Od prenove oziroma delne rekonstrukcije v letih 19921999 dalje objekt služi v kulturne namene. Prenova, ki je potekala pod vodstvom ZVKDS, se je izkazala za veliko zahtevnejšo, kot se je sprva predvidevalo. Izvedene prenove vsaj v strokovni literaturi niso problematizirali in je služila tako po arhitekturni lupini kot stavbnih elementih za referenčni primer pri poskusih (vizualnih) rekonstrukcij sorodnih spomenikov v tujini. Vendar je že sama prenova pustila veliko odprtih vprašanj, predvsem kar se tiče stavbnih faz v času judovske in kasneje krščanske uporabe stavbe. $V$ članku je predstavljena zgodovina spomeniškovarstvene dokumentacije in po-

\author{
Damjan Prelovšek \\ Jože Plečnik's Extension of his Brother Andrej's House \\ in Trnovo
}

1.01 Original scientific article

Insight into the architect's previously unread epistolary heritage and some other historical sources profoundly changes our knowledge about the origin and furnishings of Plečnik's home in Trnovo. The main reason for the construction of the cylindrical extension (1923-1924) was to create a common home for the brothers and sister, but it was not successful because of their different destinies. At first, they were all enthusiastic about the house at present-day 10 Ciril-Metod Square, where the sister lived, however, when Andrej Plečnik returned from Idrija, he decided to buy a house behind the Trnovo church in Ljubljana. The claim that Jože quarrelled with the youngest Janez, who then left the house in Trnovo, also needs to be corrected. In reality, they never lived there together. Moreover, the older brother Andrej did not enjoy his property for long, since the disciplinary committee drove him away from the Ljubljana Realschule, where he taught catechesis. He left to be a catechetic in Kočevje and never permanently returned to Ljubljana. In the end, the architect remained alone in the house and furnished it according to his own liking.

Keywords: 20th century architecture, Jože Plečnik, Andrej Plečnik, Dr. Janez Plečnik, Marija Matkovič, Terezija Gaber's house, Plečnik house in Trnovo, extension plans, extension furnishings, utopia of a common home

\section{Janez Premk \\ Maribor Synagogue Reexamined}

\subsection{Review Article}

The Maribor Synagogue is one of the most important preserved medieval synagogues in Central Europe. Since undergoing renovation and partial reconstruction from 1992-1999, the facility has served as a cultural centre. The renovation, which was supervised by the ZVKDS (Institute for the Protection of Cultural Heritage of Slovenia), proved to be much more demanding than was originally foreseen. While the outcome of the renovation has not been scrutinised in professional literature, its architectural shell and elements have served as a reference point for the (visual) reconstruction attempts of similar monuments abroad. However, the renovation itself has left numerous unanswered questions, especially in regard to the building phases during the Jewish and later Christian 
segov na objektu v 20. stoletju v luči napredka stroke pri raziskavah srednjeveških sinagog. Na primeru sporne interpretacije nekaterih stavbnih členov in neupoštevanja arheoloških raziskav je postavljena pod vprašaj celotna rekonstrukcija.

Ključne besede: judovska dediščina, sinagogalna arhitektura, srednjeveške sinagoge, srednja Evropa, Maribor, spomeniško varstvo

\section{Tanja Zimmermann}

Oto Bihalji-Merin in koncept »naivnih « v petdesetih letih 20. stoletja. Most med socialističnim realizmom in nefiguralno umetnostjo

\subsection{Izvirni znanstveni članek}

Jugoslovanski pisatelj, umetniški kritik in kustos Oto Bihalji-Merin (1904-1993) je v dvajsetih letih prejšnjega stoletja živel v Berlinu, kjer se je pridružil nemški komunistični partiji in objavljal literarno kritiko v levičarskem tisku pod sovjetskim vplivom. Rojen v židovski družini $\mathrm{v}$ Zemunu, je po vzponu nacističnega režima $\mathrm{v}$ tridesetih letih emigriral najprej v Češkoslovaško, potem pa v Francijo in Švico. Ob izbruhu druge svetovne vojne se je kot jugoslovanski vojak znašel v nemškem ujetništvu. Po vojni je postal eden najpomembnejših kulturnih teoretikov in administratorjev v Titovi Jugoslaviji. Po sporu Tita s Stalinom je postal goreč zagovornik naivne ljudske umetnosti kot prvobitnega in pristnega izraza proletarske in kmečke ustvarjalnosti. Merinova doktrina, ki je služila za premostitev razlik med socialističnim realizmom in zahodno nefiguralno umetnostjo, je temeljila na teoretskih idejah o tretji poti Mirolsava Krleže in gibanju neuvrščenih.

Ključne besede: Oto Bihalji-Merin, naivni, primitivni, socialistični realizem, nefigurativno slikarstvo, abstrakcija, »tretja pot«, Expo 58, gibanje neuvrščenih, Jugoslavija use of the building. The article examines the history of the monument's documentation and preservation in the 20th century in light of recent progress in medieval synagogue research. Owing to the controversial interpretations of certain architectural elements and the failure to take archaeological research into account, the entire reconstruction is called into question.

Keywords: Jewish heritage, synagogue architecture, medieval synagogues, Central Europe, Maribor, heritage protection

\section{Tanja Zimmermann}

Oto Bihalji-Merin and the Concept of the "Naïve" in the 1950s. Bridging Socialist Realism and Non-Figurative Art

\subsection{Original scientific article}

Yugoslav writer, art critic and curator Oto Bihalji-Merin (1904-1993) lived in Berlin during the 1920s, where he joined the German Communist Party and published literary critique in the left-wing press. Born into a Jewish family, he moved to Czechoslovakia, France, Switzerland, and Spain after the rise of the Nazi regime. In this period, he established close contact with left-wing intellectuals from all over Europe. During the Second World War, he was imprisoned as a Yugoslav soldier by the Germans. After the war, he became the most important cultural theorist and administrator in Tito's Yugoslavia. After Tito's break with Stalin, he promoted the concept of naïve folk art as an authentic, primordial expression of proletarian and peasant creativity. His doctrine, destined to bridge the gap between socialist realism and Western non-figurative art, was inspired by Miroslav Krleža’s cultural theory of the Third Way and by the non-aligned movement.

Keywords: Bihalji-Merin, naïve, primitive, socialist realism, non-figurative art, abstraction, Third Way, Expo 58, Non-Aligned Movement, Yugoslavia 



\section{SODELAVCI}

\section{CONTRIBUTORS}

Izr. prof. dr. Jasmina Čubrilo

Odeljenje za istoriju umetnosti

Filozofski fakultet

Univerzitet u Beogradu

18-20 Čika Ljubina Street

SR-11000 Beograd

jasmina.cubrilo@f.bg.ac.rs

\author{
Akad. prof. dr. Milček Komelj \\ Glinškova ploščad 20e \\ SI-1000 Ljubljana \\ sumi.komelj@gmail.com
}

\section{Vesna Krmelj}

ZRC SAZU, Umetnostnozgodovinski inštitut

Franceta Steleta

Novi trg 2

SI-1000 Ljubljana

vesna.krmelj@zrc-sazu.si

Izr. prof. dr. Barbara Murovec

ZRC SAZU, Umetnostnozgodovinski inštitut

Franceta Steleta

Novi trg 2

SI-1000 Ljubljana

Bamurovec@zrc-sazu.si

\section{Doc. dr. Mija Oter Gorenčič}

ZRC SAZU, Umetnostnozgodovinski inštitut

Franceta Steleta

Novi trg 2

SI-1000 Ljubljana

moter@zrc-sazu.si

\author{
Dr. Friedrich Polleroß \\ Institut für Kunstgeschichte \\ Die Historisch-Kulturwissenschaftliche Fakultät \\ Universität Wien \\ Garnisongasse 13, Universitätscampus Hof 9 \\ A-1090 Wien \\ friedrich.polleross@univie.ac.at
}

\author{
Dr. Damjan Prelovšek \\ Zarnikova ulica 11 \\ SI-1000 Ljubljana \\ damjan.prelovsek@zrc-sazu.s
}

\section{Dr. Janez Premk}

Raziskovalno dokumentacijski center JAS

Poljanski nasip 52

SI-1000 Ljubljana

janez.premk@jas-center.eu

Prof. dr. dr. Tanja Zimmermann

Institut für Kunstgeschicte

Fakultät für Geschichte, Kunst und

Orientwissenschaften

Universität Leipzig

Dittrichring 18-20

D-04109 Leipzig

tanja.zimmermann@uni-leipzig.de 



\section{VIRI ILUSTRACIJ \\ PhOTOGRAPHIC CREDITS}

Jasmina Čubrilo

1: Arhiv družine Protić.

2-5: J. Čubrilo.

\section{Milček Komelj}

1-18: @ ZRC SAZU, Umetnostnozgodovinski inštitut Franceta Steleta, Ljubljana (fototeka).

\section{Vesna Krmelj}

1: Arhiv avtorice.

2: ๑ ZRC SAZU, Umetnostnozgodovinski inštitut Franceta Steleta, Ljubljana (fototeka).

3-6: ๑ Biblioteka SAZU.

\section{Barbara Murovec}

1: Arhiv Občine Brežice

2, 9: @ ZRC SAZU, Umetnostnozgodovinski inštitut Franceta Steleta, Ljubljana

(foto: Andrej Furlan).

3: Biblioteca comunale degli intronati, Siena.

4, 6: ๑ ZRC SAZU, Umetnostnozgodovinski inštitut Franceta Steleta, Ljubljana (fototeka).

5, 7: ๑ Schloss \& Park Eggenberg/Universalmuseum Joanneum GmbH.

8: ( ) INDOK center, Ministrstvo za kulturo Republike Slovenije.

10: https://commons.wikimedia.org/wiki/File:Jean_Nocret_-_Louis_XIV_et_la_famille_royale_-_

Google_Art_Project.jpg

\section{Mija Oter Gorenčič}

1, 3, 5, 7, 10, 11, 12, 13, 14, 17, 20, 21: ๑ ZRC SAZU, Umetnostnozgodovinski inštitut Franceta Steleta, Ljubljana (foto: Andrej Furlan).

2, 6, 8, 9, 18, 19: @ INDOK center Ministrstva za kulturo RS, Ljubljana.

4: J. W. Valvasor, Topographia Ducatus Carnioliae Modernae, Bogenšperk 1679.

15, 16: Barbara Žabota.

\section{Friedrich Polleroß}

1: ๑ Österreichische Nationalbibliothek, Dunaj.

2-5, 7, 11: F. Polleroß.

6: () Narodna galerija, Ljubljana (foto: Bojan Salaj).

8: @ Magyar Nemzéti Muzeum, Budimpešta.

9: Wikimedia Commons. 


\section{Damjan Prelovšek}

1-9, 11-12, 15: (C) Muzej in galerija mesta Ljubljane, Plečnikova zbirka, Ljubljana.

10: zasebna zbirka.

13-14, 16: (C) Muzeum hlavního města Prahy, Praga.

\section{Janez Premk}

1: Wikipedia, open source, (c) CC CY-SA 4.0.

2, 24-26, 29: (c) Raziskovalno-dokumentacijski center JAS, Ljubljana (foto: Janez Premk).

3: Wikimedia commons, (c) Peter Lauppert - CC By-SA 3.0 at.

4-8, 17: (c) Raziskovalno-dokumentacijski center JAS, Ljubljana (risba: Anja Premk).

9: (c) ZRC SAZU, Umetnostnozgodovinski inštitut Franceta Steleta, Ljubljana.

10-13: (c) INDOK center Ministrstva za kulturo RS, Ljubljana.

14-16, 19: (c) Pokrajinski arhiv Maribor.

18: (c) Steiermärkisches Landesarchiv, Graz.

20-23, 27: (c) Zavod za varstvo kulturne dediščine RS, Območna enota Maribor.

28: (c) ZRC SAZU, Umetnostnozgodovinski inštitut Franceta Steleta, Ljubljana (foto: Andrej Furlan).

\section{Tanja Zimmermann}

1-2: 50 Jahre moderne Kunst, Köln 1959.

3-4: O. Bihalji-Merin, Tradition und Perspektiven, Jugoslawien. Zeitgenössische jugoslawische Malerei, Beograd 1957. 

Vse pravice pridržane. Noben del te izdaje ne sme biti reproduciran, shranjen ali prepisan v kateri koli obliki oz. na kateri koli način, bodisi elektronsko, mehansko, s fotokopiranjem, snemanjem ali kako drugače, brez predhodnega dovoljenja lastnika avtorskih pravic (copyright).

All rights reserved. No part of this publication may be reproduced, stored in a retrieval system or utilized in any form or by any means, electronic or mechanical, including photocopying, recording or otherwise, without prior permission of the copyright owner.

Za avtorske pravice reprodukcij odgovarjajo avtorji objavljenih prispevkov.

The copyrights for reproductions are the responsibility of the authors of published papers. 


\section{ACTA HISTORIAE ARTIS SLOVENICA 23|1・ 2018}

\section{Vsebina $\cdot$ Contents}

Milček Komelj, Ob 70-letnici Umetnostnozgodovinskega inštituta Franceta Steleta. Nagovor na slavnostni akademiji 14. decembra 2017 v Prešernovi dvorani SAZU • France Stele Institute of Art History's 70th Anniversary. The Opening Speech at the Celebration on 14 December 2017 at the Prešeren Hall SAZU

Mija Oter Gorenčič, Pro remedio et pro salute animae nostrae. Memoria v srednjeveškem umetnostnem okrasju cisterce v Stični kot odsev tesne povezanosti s plemstvom • Pro remedio et pro salute animae nostrae. Memoria in Medieval Architectural Decoration of the Stična Cistercian Monastery as a Reflection of its Close Connection with the Nobility

Janez Premk, Maribor Synagogue Reexamined • Mariborska sinagoga pod drobnogledom

Friedrich Polleroß, Die Immaculata, Kaiser Leopold I., und ein römisches Thesenblatt der Laibacher Franziskaner • Brezmadežna, cesar Leopold I. in rimski tezni list ljubljanskih frančiškanov

Barbara Murovec, Historizirana podoba naročnika. Attemsova družinska portreta iz brežiškega gradu in Rembov avtoportret • The Patron's Historized Image. Attems' Family Portraits and Remp's Self-Portrait in the Brežice (Rann) Castle

Vesna Krmelj, France Stele v luči mladostne korespondence z Izidorjem Cankarjem • An Insight into France Stele through his Early Adulthood Correspondence with Izidor Cankar

Tanja Zimmermann, Oto Bihalji-Merin and the Concept of the "Naìve" in the 1950s. Bridging Socialist Realism and Non-Figurative Art • Oto Bihalji-Merin in koncept "naivnih« v petdesetih letih 20. stoletja. Most med socialističnim realizmom in nefiguralno umetnostjo

Jasmina Čubrilo, Yugoslav: Toponym or Ideology in Miodrag B. Protic's Art-Historical Systematization of 20thCentury Art • Jugoslovansko: toponim ali ideologija v umetnostnozgodovinski sistematizaciji umetnosti 20. stoletja v besedilih Miodraga B. Protića

Damjan Prelovšek, Plečnikov prizidek k bratovi hiši v Trnovem • Jože Plečnik's Extension of his Brother Andrej's House in Trnovo

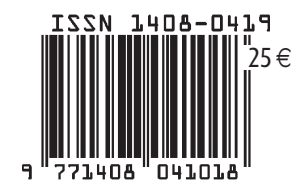

